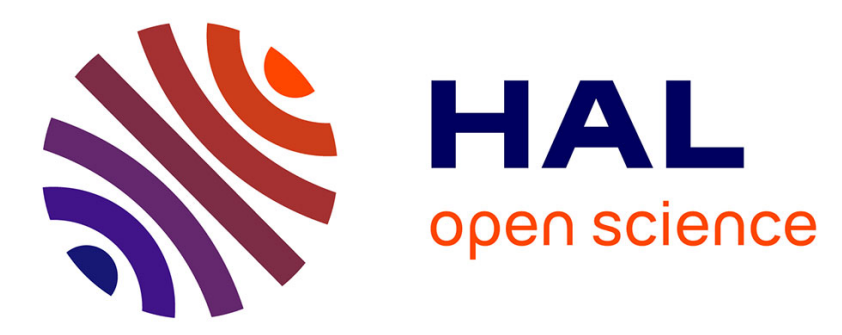

\title{
Comparison of different methods for extraction from Tetraclinis articulata: Yield, chemical composition and antioxidant activity
}

\author{
Nejia Herzi, Jalloul Bouajila, Séverine Camy, Mehrez Romdhane, \\ Jean-Stéphane Condoret
}

\section{To cite this version:}

Nejia Herzi, Jalloul Bouajila, Séverine Camy, Mehrez Romdhane, Jean-Stéphane Condoret. Comparison of different methods for extraction from Tetraclinis articulata: Yield, chemical composition and antioxidant activity. Food Chemistry, 2013, vol. 141, pp. 3537-3545. 10.1016/j.foodchem.2013.06.065 . hal-00875913

\section{HAL Id: hal-00875913 \\ https://hal.science/hal-00875913}

Submitted on 23 Oct 2013

HAL is a multi-disciplinary open access archive for the deposit and dissemination of scientific research documents, whether they are published or not. The documents may come from teaching and research institutions in France or abroad, or from public or private research centers.
L'archive ouverte pluridisciplinaire $\mathbf{H A L}$, est destinée au dépôt et à la diffusion de documents scientifiques de niveau recherche, publiés ou non, émanant des établissements d'enseignement et de recherche français ou étrangers, des laboratoires publics ou privés. 


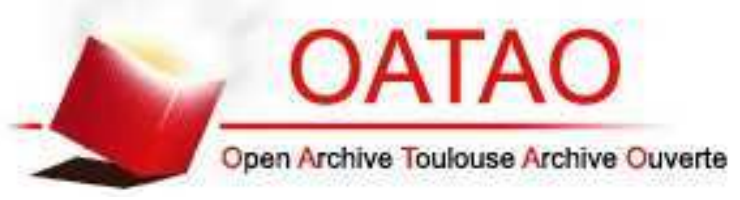

\section{Open Archive TOULOUSE Archive Ouverte (OATAO)}

OATAO is an open access repository that collects the work of Toulouse researchers and makes it freely available over the web where possible.

This is an author-deposited version published in : http://oatao.univ-toulouse.fr/ Eprints ID : 9749

To link to this article : DOI: 10.1016/j.foodchem.2013.06.065

URL : http://dx.doi.org/10.1016/j.foodchem.2013.06.065

To cite this version : Herzi, Nejia and Bouajila, Jalloul and Camy, Séverine and Romdhane, Mehrez and Condoret, Jean-Stéphane Comparison of different methods for extraction from Tetraclinis articulata: Yield, chemical composition and antioxidant activity. (2013) Food Chemistry, vol. 141 ( $\mathrm{n}^{\circ}$ 4). pp. 3537-3545. ISSN 0308-8146

Any correspondance concerning this service should be sent to the repository administrator: staff-oatao@ listes-diff.inp-toulouse.fr 
Analytical Methods

\title{
Comparison of different methods for extraction from Tetraclinis articulata: Yield, chemical composition and antioxidant activity
}

\author{
Nejia Herzi ${ }^{\mathrm{a}, \mathrm{b}}$, Jalloul Bouajila ${ }^{\mathrm{c}, *}$, Séverine Camy ${ }^{\mathrm{b}}$, Mehrez Romdhane ${ }^{\mathrm{a}}$, Jean-Stéphane Condoret ${ }^{\mathrm{b}, *}$ \\ anité de recherche MACS, ENIG, Route de Médenine, 6029 Gabès, Tunisia \\ ${ }^{\mathrm{b}}$ Université de Toulouse, INPT, UPS, Laboratoire de Génie Chimique, UMR CNRS 5503, 4 Allée Emile Monso, F-31030 Toulouse, France \\ ' Université de Toulouse, Laboratoire des Interactions Moléculaires et Réactivité Chimique et Photochimique, UMR CNRS 5623, Université Paul-Sabatier, 118 Route de Narbonne, \\ F-31062 Toulouse, France
}

Keywords:

Tetraclinis articulata essential oil

Soxhlet extraction

Hydrodistillation

Supercritical carbon dioxide

Antioxidant activity

\begin{abstract}
A B S T R A C T
In the present study, three techniques of extraction: hydrodistillation (HD), solvent extraction (conventional 'Soxhlet' technique) and an innovative technique, i.e., the supercritical fluid extraction (SFE), were applied to ground Tetraclinis articulata leaves and compared for extraction duration, extraction yield, and chemical composition of the extracts as well as their antioxidant activities. The extracts were analyzed by GC-FID and GC-MS. The antioxidant activity was measured using two methods: ABTS ${ }^{\circ+}$ and DPPH $^{*}$. The yield obtained using HD, SFE, hexane and ethanol Soxhlet extractions were found to be 0.6, 1.6, 40.4 and $21.2-27.4 \mathrm{~g} / \mathrm{kg}$ respectively. An original result of this study is that the best antioxidant activity was obtained with an SFE extract $(41 \mathrm{mg} / \mathrm{L})$. The SFE method offers some noteworthy advantages over traditional alternatives, such as shorter extraction times, low environmental impact, and a clean, non-thermally-degraded final product. Also, a good correlation between the phenolic contents and the antioxidant activity was observed with extracts obtained by SFE at $9 \mathrm{MPa}$.
\end{abstract}

\section{Introduction}

With the incentive of following Green Chemistry principles and increasing interest of consumers in functional foods, research into more effective and cleaner extraction of natural products using 'natural' processes is on-going, especially in relation to aromatic and medicinal plants (AMP), the essential oils (EOs) of which have been reported to offer other biological activities. The need for these other biological activities from natural products has been reinforced recently by the emergence of many micro-organisms that have proved to be resistant to conventional medicines. Globally, EOs can be and have been employed in the pharmaceutical, food, cosmetic and perfume industries and also to control post-harvest diseases (Rashid, Rather, Shah, \& Bhat, 2013; Sacchetti et al., 2005; Sanchez-Gonzalez, Vargas, Gonzalez-Martınez, Chiralt, \& Chafer, 2011). Approximately 3000 EOs are known, 300 of them having commercial importance (Khajeh, Yamini, \& Shariati, 2010; Shee, Raja, Sethi, Kunhambu, \& Arunachalam, 2010). However, many plants still remain unstudied. For instance, very few works

* Corresponding author. Address: Université de Toulouse, INPT, UPS, Laboratoire de Génie Chimique, 4 Allée Emile Monso, F-31030 Toulouse, France. Tel.: +33 5 34323713 (J.-S. Condoret). Address: Université de Toulouse, IMRCP UMR 5623. Tel.: +33562256885 (J. Bouajila).

E-mail addresses: jalloul.bouajila@univ-tlse3.fr (J. Bouajila), jeanstephane. condoret@ensiacet.fr (J.-S. Condoret).
(Barrero et al., 2003; Ben Hadj Ahmed et al., 2011) have been devoted to Tetraclinis articulata.

This plant belongs to the family Cupressaceae and is native plant of the South-Western Mediterranean, mainly North Africa. It is an important element of the Maghreb vegetation (Morocco, Algeria and Tunisia).

T. articulata is a high quality health food, which is commonly used in Tunisian traditional medicine, because of identified pharmacological effects, including antioxidant activity that may explain the benefits in treating circulatory disorders perceived from the use of the herb over the centuries (Bourkhiss, Hnach, Paolini, Costa, Farah \& Satrani, 2010). So, the macerated leaves were used by oral administration such as the herbal teas. Moreover, T. articulata was used as anti-diabetic plants which allow reducing the use of traditional medicines used in the treatment of diabetes (Patel, Kumar, Laloo, \& Hemalatha, 2012).

The EO of such plants is traditionally extracted by hydrodistillation (HD). However, this technique presents many disadvantages such as long extraction times, which result in the degradation of unsaturated compounds (due to the high temperature, which is around $100{ }^{\circ} \mathrm{C}$ ), low yield and losses of volatile compounds (Costa et al., 2012; Schaneberg \& Khan, 2002; Yamini, Khajeh, Ghasemi, Mirza, \& Javidnia, 2008).

Alternative methods have been proposed for extracting natural products, and more particularly volatile fractions, from plants by using supercritical fluid extraction (SFE) and extensive reviews 
and articles exist on the topic (Costa et al., 2012; Grosso, Ferraro, Figueiredo, Barroso, \& Palavra, 2008; Herrero, Mendiola, Cifuentes, \& Ibanez, 2010; Khajeh, Yamini, Sefidkon, \& Bahramifar, 2004; Reverchon, 1997). SFE is based on the use of supercritical carbon dioxide as the solvent of extraction. SFE of volatile fractions is operated at moderate pressure ( $9 \mathrm{MPa}$ ) and relatively low temperatures $\left(40-60^{\circ} \mathrm{C}\right)$. An important characteristic of this technique is the potential to modify the solvent, and therefore selectivity of the process, by changing solvent density using pressure and temperature variation (Reverchon, 1997; Vergas, Mendes, Azevedo, Pessoa, \& Uller, 2010). A crucial advantage of this technique over HD or Soxhlet extraction is that it involves a relatively short exposure time to a solvent, which is at low temperature. In addition, high yields, lower energy requirements and high purity of the extract are obtained (Guan, Li, Yan, Tang \& Quan, 2007; Khajeh, Yamini, Sefidkon, \& Bahramifar, 2004).

The use of carbon dioxide as the supercritical fluid is explained mainly by the properties of $\mathrm{CO}_{2}$, which is a safe, non-combustible, inexpensive, odorless, colorless, tasteless, and readily available solvent. Its low viscosity enables it to penetrate the matrix to reach the material to be extracted, and its low latent heat of vaporization and high volatility mean that it can be removed easily without leaving solvent residue. By varying the temperature and pressure of the $\mathrm{CO}_{2}$ during extraction, different components can be selectively extracted (Morales, Berry, McIntyre, \& Aparicio, 1998; Reverchon, Ambruosi, \& Senatore, 1994). Finally, the prominent advantage of $\mathrm{CO}_{2}$ for the processing of natural products undoubtedly lies in its non-toxicity, which makes it acceptable for the industry and ensures 'clean' characteristics of the extracted products.

In the present study, three techniques of extraction HD, solvent extraction and SFE were compared. This work provides a brief overview on the principal application of clean processing for isolating natural products from $T$. articulata although special attention is given to the extraction of antioxidant compounds because of their important role in food preservation and health promotion. Note that it is well known that antioxidant activity detected by in vitro experiments may be non-effective in vivo. This aspect was not considered here and would need further investigation.

The main objective of this study was to compare these methods by identifying and quantifying the chemical composition of each extract and also by determining their antioxidant activity.

\section{Materials and methods}

\subsection{Plant material}

T. articulata is a traditional medicinal plant used in Tunisia, Morocco and Algeria. Leaves from cultivated plants of $T$. articulata were collected by hand during October 2010 (morning) from the same location Korbos, located in the region of Cap Bon at $60 \mathrm{~km}$ from Tunis (latitudes $36.82 / 36^{\circ} 49^{\prime} 44^{\prime \prime}$ and longitudes $10.59 / 10^{\circ}$ $\left.35^{\prime} 36^{\prime \prime}\right)$, Tunisia. Harvested material was dried in the air, protected against direct sunlight, until a constant weight was achieved. The average particle size of $T$. articulata obtained after sieving of grinding leaves (using laboratory knife grinder) was $0.8 \mathrm{~mm}$. The moisture content of the air-dried plant material, determined by Karl Fischer volumetric titration, was $9 \% \mathrm{w} / \mathrm{w}$.

\subsection{Chemicals}

All chemicals were of analytical reagent grade. All reagents were purchased from Sigma-Aldrich-Fluka (Saint-Quentin, France). Commercial carbon dioxide (99.99\% purity) was purchased from Air Liquide (Bordeaux, France) for the extraction of volatile components by SFE extraction.

\subsection{Extraction methods}

\subsubsection{Hydrodistillation}

HD was operated in a conventional Clevenger-type apparatus. This set-up was composed of a 2-L boiler, a condenser and a measuring tube with a stopcock. A return tube for the aqueous part of the distillate allowed the cohobation technique to be used. Dried leaves of $T$. articulata $(100 \mathrm{~g})$ were subjected to HD with $1 \mathrm{~L}$ of water for $180 \mathrm{~min}$. The volatile distillate was collected over anhydrous sodium sulfate and refrigerated at $4{ }^{\circ} \mathrm{C}$ prior to analysis.

\subsubsection{Supercritical fluid extraction}

A SFE200 extraction pilot unit with three cyclonic separators from SEPAREX (France) was used. The $115 \mathrm{~mL}$ stainless steel extraction tank was loaded with $50 \mathrm{~g}$ of dried $T$. articulata leaves. The system was operated at a constant temperature of $40^{\circ} \mathrm{C}$ and a pressure of $9 \mathrm{MPa}$ for recovery of the volatile fraction. For all experiments, conditions in the recovery section were set at $5 \mathrm{MPa} / 30^{\circ} \mathrm{C}$ in the first separator, $5 \mathrm{MPa} / 25^{\circ} \mathrm{C}$ in the second one and $0.1 \mathrm{MPa} / 20^{\circ} \mathrm{C}$ in the last one.

\subsubsection{Soxhlet extraction}

Ground T. articulata leaves ( $100 \mathrm{~g}$ ) were extracted with $400 \mathrm{~mL}$ of ethanol or hexane (99\% purity) during $6-8 \mathrm{~h}$ in a conventional Soxhlet apparatus ( $500 \mathrm{~mL}$ boiler). At the end of extraction, the liquid extract was filtered and evaporated to complete dryness in a vacuum at $35^{\circ} \mathrm{C}$ using a rota-vapor apparatus. Finally, the dried extract was stored at $4{ }^{\circ} \mathrm{C}$ for further studies. All experiments were performed in triplicate. These two solvents were chosen because of their opposite polarities allowing extracting different kinds of compounds (non polar to polar).

\subsection{Chemical components analysis: GC-FID and GC-MS}

Quantitative and qualitative analysis of the extracts were carried out by gas chromatography-flame ionization detection (GC-FID) and gas chromatography-mass spectrometry (GC-MS). Gas chromatography analyses were performed on a Varian Star 3400 Cx chromatograph (Les Ullis, France) fitted with a DB-5MS fused silica capillary column (5\% phenylmethylpolysyloxane, $30 \mathrm{~m} \times 0.25 \mathrm{~mm}$, film thickness $0.25 \mu \mathrm{m}$ ). Chromatographic conditions were a temperature rise from $60^{\circ} \mathrm{C}$ to $260^{\circ} \mathrm{C}$ with a gradient of $5{ }^{\circ} \mathrm{C} / \mathrm{min}$ and then $15 \mathrm{~min}$ at $260^{\circ} \mathrm{C}$. A second gradient of $40^{\circ} \mathrm{C} /$ min was applied to reach $340^{\circ} \mathrm{C}$. Total analysis time was $57 \mathrm{~min}$. For analysis purposes, each extract was dissolved in petroleum ether. Samples $(1 \mu \mathrm{L})$ were injected in the split mode at a ratio of $1: 10$. Helium (purity $99.999 \%$ ) was used as the carrier gas at $1 \mathrm{~mL} / \mathrm{min}$. The injector was operated at $200^{\circ} \mathrm{C}$. The mass spectrometer (Varian Saturn GC-MS-MS 4D) was adjusted for an emission current of $10 \mu \mathrm{A}$ and electron multiplier voltage between 1400 and $1500 \mathrm{~V}$. The temperature of the trap was $150^{\circ} \mathrm{C}$ and that of the transfer line was $170^{\circ} \mathrm{C}$. Mass scanning was from 40 to 650 atomic mass units.

Compounds were identified by comparison of their Retention indices (RI), obtained on a nonpolar DB-5MS column relative to C5-C24 n-alkanes, with those provided in the literature, by comparison of their mass spectra with those recorded in NIST 08 (National Institute of Standards and Technology) and reported in published articles, and by co-injection of available reference compounds. The samples were analyzed in duplicate. The percentage composition of the extract was calculated by the normalization method from the GC peak areas, assuming identical mass response factors for all compounds. Results were calculated as mean values after two injections of extract, without using correction factors. The identification is only made for the volatile compounds. 
Especially, for Soxhlet and SFE extracts, some non volatile compounds cannot be identified.

\subsection{Determination of total phenolic content}

The phenolic content of each extract was determined by the Folin-Ciocalteu method (Singleton, Orthofer, \& Lamuela-Raventós, 1999). A diluted solution of each extract $(0.5 \mathrm{~mL})$ was mixed with Folin-Ciocalteu reagent $(0.2 \mathrm{~mol} / \mathrm{L}, 2.5 \mathrm{~mL})$. This mixture was kept at room temperature for $5 \mathrm{~min}$ and then sodium carbonate solution ( $75 \mathrm{~g} / \mathrm{L}$ in water, $2 \mathrm{~mL}$ ) was added. After $1 \mathrm{~h}$ of incubation, the absorbance was measured at $765 \mathrm{~nm}$ against water blank. A standard calibration curve was plotted using gallic acid $(0-300 \mathrm{mg} / \mathrm{L})$. The results were expressed as $\mathrm{mg}$ of Gallic Acid Equivalent $(\mathrm{GAE}) / \mathrm{kg}$ of dry plant material.

\subsection{Antioxidant activity}

Two analytical methods was studied: $\mathrm{DPPH}^{\bullet}$ and $\mathrm{ABTS}^{\bullet+}$ (Thaipong, Boonprakob, Crosby, Zevallos, \& Byrne, 2006) described below.

\subsection{1. $D P P H \cdot$ free radical scavenging activity}

Antioxidant scavenging activity was determined using the 1,1-diphenyl-2-picrylhydrazyl free radical $\left(\mathrm{DPPH}^{\bullet}\right)$ as described by Blois (1958) with some modifications; various dilutions of the test materials (ascorbic acid or extracts, $1.5 \mathrm{~mL}$ ) were mixed with a $0.2 \mathrm{mM}$ methanolic DPPH ${ }^{\bullet}$ solution $(1.5 \mathrm{~mL})$. After an incubation period of $30 \mathrm{~min}$ at $25^{\circ} \mathrm{C}$, the absorbance at $520 \mathrm{~nm}$ was recorded as $A_{\text {(sample) }}$. A control experiment was also carried out by applying the same procedure to a solution without the test material and the absorbance recorded $\left(A_{\text {(blank) }}\right)$. The free radical scavenging activity of each solution was then calculated as percentage inhibition according to the following Eq.

$\% \quad$ inhibition $=100 \times\left[\left(A_{\text {(blank })}-A_{(\text {sample }))} / A_{(\text {blank })}\right]\right.$

Extract antioxidant activity was expressed as $\mathrm{IC}_{50}$, defined as the concentration of the test material required to cause a $50 \%$ decrease in initial $\mathrm{DPPH}^{\bullet}$ concentration. Values were estimated using linear regression. Ascorbic acid was used as a reference.

\subsubsection{ABTS $^{++}$radical-scavenging}

The radical scavenging capacity of the samples for the ABTS ${ }^{\bullet+}$ (2,2'-azinobis-3-ethylbenzo-thiazoline-6-sulfonate) was determined as described by Re, Pellegrini, Proteggente, Pannala, Yang and Rice-Evans (1999). ABTS $^{\bullet+}$ was generated by mixing a $7 \mathrm{mM}$ solution of $\mathrm{ABTS}^{\circ+}$ at $\mathrm{pH} 7.4\left(5 \mathrm{mM} \mathrm{NaH}_{2} \mathrm{PO}_{4}, 5 \mathrm{mM} \mathrm{Na}_{2-}\right.$ $\mathrm{HPO}_{4}$ and $154 \mathrm{mMNaCl}$ ) with $2.5 \mathrm{mM}$ of potassium persulfate (final concentration) and stored in the dark at room temperature for $16 \mathrm{~h}$ before use. The mixture was diluted with water to give an absorbance of $0.70 \pm 0.02$ units at $734 \mathrm{~nm}$ using spectrophotometry. For each sample, a diluted methanol solution of the sample $(100 \mu \mathrm{L})$ was allowed to react with fresh $\mathrm{ABTS}^{\bullet+}$ solution $(900 \mu \mathrm{L})$, and the absorbance was measured $6 \mathrm{~min}$ after initial mixing. Ascorbic acid was used as a reference and the free radical scavenging capacity was expressed by $\mathrm{IC}_{50}(\mathrm{mg} / \mathrm{L})$ values, which denote the concentration required to scavenge $50 \%$ of $\mathrm{ABTS}^{\circ+}$. The free radical scavenging capacity $\mathrm{IC}_{50}$ was determined using the same equation as used previously for the $\mathrm{DPPH}^{\bullet}$ method.

\subsection{Statistical analysis}

All data were expressed as means \pm standard deviations of triplicate measurements. The confidence limits were set at $P<0.05$.
Correlations were sought using the correlation and regression functions available in Excel software (Microsoft ${ }^{\circledR}$ Office). Standard deviations (SD) did not exceed $5 \%$ for the majority of values obtained. Data analysis procedure (ANOVA) was performed in order to assess the data.

\section{Results and discussion}

\subsection{Operation of the different techniques of extraction}

In order to estimate the potential for extracting different natural substances from $T$. articulata leaves, HD, Soxhlet extraction and SFE (at $9 \mathrm{MPa}$ and $40^{\circ} \mathrm{C}$ ) were performed. For each extraction method, the global yield was defined as $\mathrm{Y}=\mathrm{g}$ of oil extracted $/ \mathrm{kg}$ of plant material loaded into the extractor. The yield was measured for each run and averaged for triplicate experiments.

Extraction methods were firstly compared in terms of extraction yields and, in particular, the influence of the main operating parameters. The best operating conditions, in terms of obtained global yield, were defined for each of the three extraction processes. In a second part, the chemical composition and antioxidant activity of the extracts were compared.

The brownish-yellow SFE extracts and dark green Soxhlet extracts were semi-solid under ambient conditions $\left(20^{\circ} \mathrm{C}\right.$ and $0.1 \mathrm{MPa}$ ) while the oil obtained by HD was a transparent to pale yellow liquid with a specific odor, different from that of the untreated plant material. Conversely, the SFE extracts had an aroma very similar to that of the untreated plant material.

\subsubsection{Hydrodistillation}

The choice of the best operating conditions was done by varying the extraction time $(0-300 \mathrm{~min})$, the ratio of the mass of water to the mass of plant material $(R=8,10,12$ and 14$)$, and the condensation flow-rate at the condenser $(0.01,0.02,0.03$, and $0.04 \mathrm{~mL} / \mathrm{s})$. The condensation flow-rate $(\mathrm{mL} / \mathrm{s})$ is directly related to the vapor flux leaving the boiler and therefore related to the heating power at the boiler, which was set to a given value manually. Best choices of operating conditions were investigated to obtain the highest yield of EO.

Fig. 1 presents the time variation of the global extraction yield (Y) obtained by HD. The kinetics of extraction presented in Fig. 1-a exhibits a very conventional shape, indicating a first step of rapid extraction and then a slow-down due to the decrease of the solute concentration in the solid. From this curve, it can be seen that extraction is mostly complete after $180 \mathrm{~min}$. Fig. 1-b and -c show the influence of the water/plant-material ratio and the influence of the condensation flow-rate for extraction duration of $180 \mathrm{~min}$. Both curves present an optimum. Fig. 1-b indicates that a minimum volume of water $(R=10)$ is necessary to obtain an efficient solid-liquid boiling system (or a solute unsaturated liquid phase) and also that too much water $(R>12)$ is detrimental for the yield, probably because it induces loss of water-soluble compounds in the overlarge volume of water. This negative influence of excessive values of the water/plant-material ratio was also observed by Sovová and Aleksovski (2006), and this was explained by their modeling approach.

In Fig. 1-c, it can be seen that a low vapor flux (i.e., condensation flow-rate $<0.02 \mathrm{~mL} / \mathrm{s}$ ) gave a low extraction yield because it slowed the kinetics. When there is no internal mass transfer limitation, the recovery rate in the separator is directly proportional to the vapor flow. So, more time is necessary to obtain the same yield at low vapor fluxes, and the extraction was probably not complete after $180 \mathrm{~min}$. A further increase in the vapor flow rate would ultimately yield a plateau. Nevertheless, in our case, increased vapor flow $(0.045 \mathrm{~mL} / \mathrm{s})$ lowered the global yield. A probable explanation is 

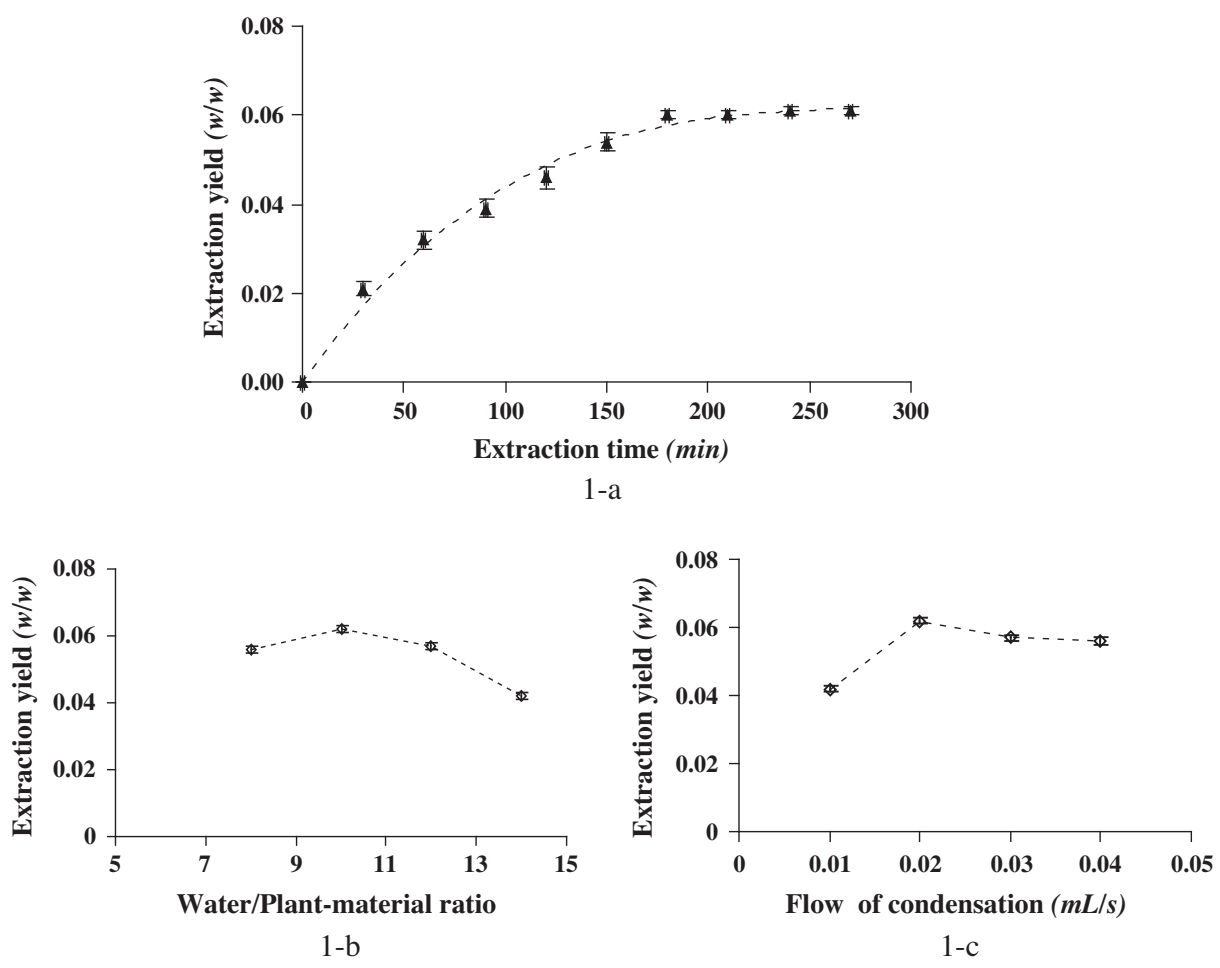

Fig. 1. Extraction yield of hydrodistillation for $100 \mathrm{~g}$ of raw material. (a) Kinetics of extraction with a condensation flow-rate of $0.02 \mathrm{~mL} / \mathrm{s}$ and a Water/Plant-material ratio of 10 , (b) Influence of the Water/Plant-material ratio for an extraction time of $3 \mathrm{~h}$ and a condensation flow-rate of $0.02 \mathrm{~mL} / \mathrm{s}$, and (c) Influence of the condensation flow-rate for an extraction time of $3 \mathrm{~h}$ and a Water/Plant-material ratio of 10.

that the condenser capacity was too small for this volume of steam, which led to loss of oil in the non-condensed vapor phase at the top of the condenser.

Finally, the best choice of operating extraction conditions for the $T$. articulata HD process were found to be $3 \mathrm{~h}$ duration, $0.02 \mathrm{~mL} / \mathrm{s}$ condensation flow-rate and a water/plant-material ratio $R$ equal to 10 .

\subsubsection{Supercritical $\mathrm{CO}_{2}$ extraction (SFE)}

For the SFE process, the extraction pressure and temperature, $\mathrm{CO}_{2}$ flow-rate, particle size and extraction duration are generally considered as the most important factors that influence extraction efficiency. The influence of each parameters:temperature (at three levels of 40,50 and $60^{\circ} \mathrm{C}$ ), pressure (using four levels of $9,15,28$ and $100 \mathrm{MPa}$ ), flow rate of $\mathrm{CO}_{2}$ (five flow rate 5, 10, 15, 20 and $30 \mathrm{~g} / \mathrm{min}$ ) and particle size (four values of $0.5<\mathrm{dp}<1.2$; $1.2<\mathrm{dp}<1.8 ; 1.8<\mathrm{dp}<2.5$; and $\mathrm{dp}>2.5 \mathrm{~mm}$ ) on the global extraction yield is shown in Fig. 2 .

Fig. 2-a presents an example of kinetics of the extraction process. The shape of the curve suggests that extraction is mainly limited by the solubility of oil in $\mathrm{CO}_{2}$ or by solid-fluid equilibrium. As expected, on Fig. 2-b, an increase in extraction pressure had a strong positive influence on the global yield of extraction. Pressure has a direct effect on the density of $\mathrm{CO}_{2}$, increasing its solvent power. However, high extraction pressure favors the extraction of heavy compounds such as lipids or waxes. As volatile fractions of plant material are soluble in supercritical $\mathrm{CO}_{2}$ at $9 \mathrm{MPa}$, selectivity for these compounds was not favored by high extraction pressure. Such conditions are mentioned several times in the literature and were confirmed by a preliminary study of the plant material (Gomes, Mata, \& Rodrigues, 2007; Sovova, Komers, Kucera, \& Jez, 1994).

Fig. 2-c shows that an increase in temperature, inducing a decrease in $\mathrm{CO}_{2}$ density, leads to a decrease in the global extraction yield. This may be related to the retrograde solubility effect described for example by da Francisco and Sivik (2002) where increased vapor pressure is not sufficient to balance the loss of solvent power due to the decreased $\mathrm{CO}_{2}$ density when temperature is increased.

Fig. 2-d indicates that, for $60 \mathrm{~min}$ of extraction, a $\mathrm{CO}_{2}$ flow rate of $20 \mathrm{~g} / \mathrm{min}$ is necessary to achieve complete extraction. The initial quasi-linear influence of the $\mathrm{CO}_{2}$ flow-rate confirms the hypothesis that this SFE process is solubility or solid-fluid equilibrium limited. The plateau obtained for high flow-rates corresponds to complete extraction. From these results, the optimal conditions for T. articulata extraction were found to be $9 \mathrm{MPa}, 40{ }^{\circ} \mathrm{C}$ and $20 \mathrm{~g} / \mathrm{min}$ of $\mathrm{CO}_{2}$ for $60 \mathrm{~min}$. Extraction was apparently complete at $30 \mathrm{~min}$ but an additional $30 \mathrm{~min}$ was included to propose a complete kinetic study and to ensure complete extraction. Indeed, SFE requires actually shorter extraction times (30 min) compared to HD ( $3 \mathrm{~h}$ ) and Soxhlet extraction (6 h).

The influence of particle size was also studied and is shown on Fig. 2-e, where optimal yield was obtained for $1.2<\mathrm{dp}<1.8$ and 1.8 $<\mathrm{dp}<2.5 \mathrm{~mm}$-diameter particles. Smaller particles gave lower yields. This was most probably related to a loss of solutes during the grinding step, as previously evidenced in a study by Khajeh, Yamini, Bahramifar, Sefidkon, and Pirmoradei (2005). During grinding, compounds including oils may be degraded either by local overheating or by being left on the grinder blades. A decrease in yield was also observed with larger particles $(>0.5 \mathrm{~mm})$, probably as a result of internal diffusional limitations inducing lower extraction kinetics and, therefore, lower yields over a given duration.

\subsubsection{Soxhlet extraction}

Hexane and ethanol, which have very different polarity properties, were tested as solvents for the Soxhlet extraction of T. articulata. Hexane extraction yield was found to be the highest $(40 \mathrm{~g} / \mathrm{kg})$ against $26.8 \mathrm{~g} / \mathrm{kg}$ for ethanol (see Table 1 ). In this study, a Solvent/ 


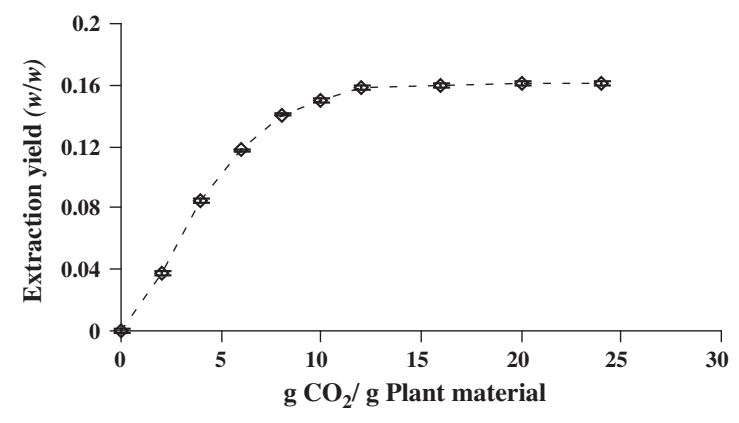

$2-\mathrm{a}$

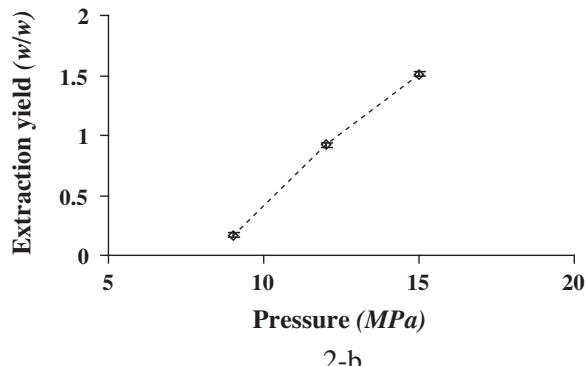

$2-b$

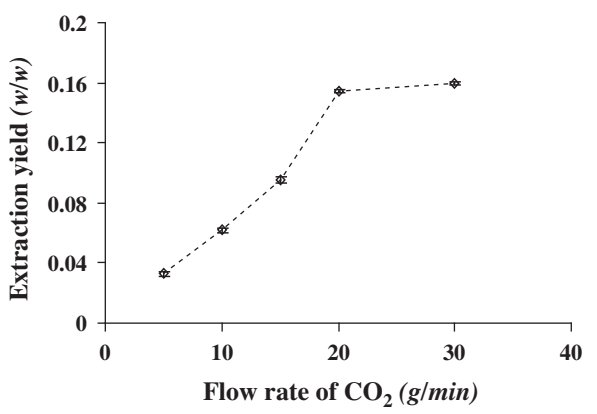

$2-d$

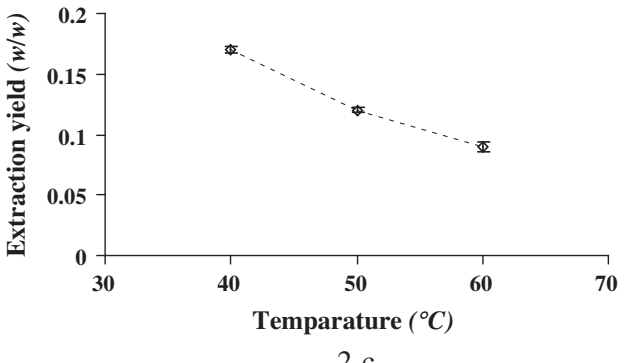

$2-\mathrm{c}$

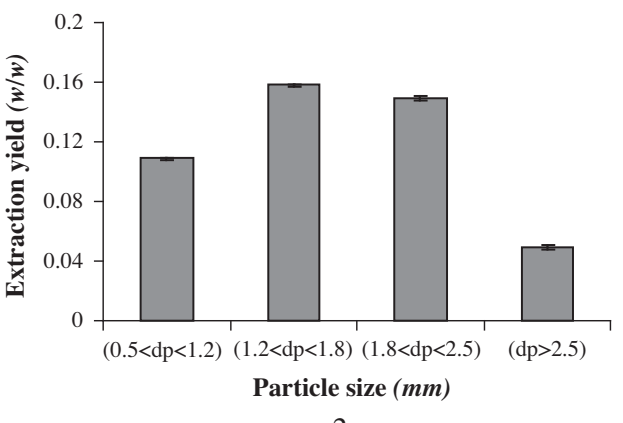

2-e

Fig. 2. Extraction yield of SFE for $50 \mathrm{~g}$ of raw material of $T$. articulata at $Q=20 \mathrm{~g} / \mathrm{min}, P=9 \mathrm{MPa}$ and $T=40^{\circ} \mathrm{C}$, (a) Kinetics of SFE extraction process at $t=60 \mathrm{~min}$, (b) Influence of the pressure on the extraction yield at $t=30 \mathrm{~min}$, (c) Influence of the temperature on the extraction yield at $t=30 \mathrm{~min}$, (d) Influence of $\mathrm{CO}_{2}$ flow-rate on the extraction yield at $t=30 \mathrm{~min}$, (e) Influence of the particle size on the SFE extraction yield at $t=30 \mathrm{~min}$.

Plant-material ratio of 4 was used. Different extraction durations were tested for ethanol. The results presented in Table 1 shows the effect of the duration on the quantity and quality of products. The best performance and quality of product were obtained for $6 \mathrm{~h}$ of extraction with ethanol.

Table 1 summarizes the results of the three extraction procedures. The hexane Soxhlet extraction provided an extraction yield of $T$. articulata equal to $40 \mathrm{~g} / \mathrm{kg}$, which is the highest yield. SFE extraction at $9 \mathrm{MPa}$ resulted in a yield of $1.6 \mathrm{~g} / \mathrm{kg}$, while the HD process gave the lowest yield, of $0.6 \mathrm{~g} / \mathrm{kg}$.

The extracts obtained with HD and SFE at 9 MPa are assumed to contain only volatile fractions of the plant. So, the extraction yield of volatile oil is increased by about $62 \%$ with SFE as compared to HD. Soxhlet extractions with ethanol or hexane lead to extracts containing volatile compounds together with high-molecular-mass compounds, which means low selectivity with respect to volatile compounds (Hawthorne, Grabanski, Martin, \& Miller, 2000). Another drawback of the Soxhlet procedure is the extraction duration $(6 \mathrm{~h})$ and the presence of organic solvent traces in the extracts.

\subsection{Effect of extraction technique on the chemical composition of the extracts}

The results of the chemical identification of all of the extracts, percentages and extracted amounts, are summarized in Table 1.
A total of 58 compounds were identified in HD extracts, 72 compounds in SFE extracts and 78 compounds in Soxhlet extracts, which accounted for $93.71 \%, 98.62 \%$ and $98.5 \%$ of the total oil composition respectively (Kelen \& Tepe, 2008; Mara, Leal, Carvalho, \& Meireles, 2003). For the sake of simplicity, the discussion has been restricted to the major components identified for the different methods. These major components are presented by 32 components present at fraction greater than $2 \%$.

The major components identified in HD extracts were $\alpha$-pinene (24.9\%), linalool acetate (21.44\%) and caryophyllene oxide (4.24\%). The major components in SFE extracts were $\alpha$-pinene (9.39$31.32 \%)$, linalool acetate (15-18.18\%), alloaromadendrene (7.55$11 \%)$ and $\gamma$-caryophyllene (4.16-6\%). The major components identified in Soxhlet extracts were $\alpha$-terpinene (13-16.65\%), trans-isolimonene (4-8.19\%), abietic acid (0-5.68\%) and linalool acetate $(5.52-7 \%)$. In the Soxhlet extracts, other major high molecular-mass components were detected but not identified by GC-MS $(8-11 \%)$

Remarkable differences concerning the nature of components and the amounts extracted were observed with respect to the type of extraction process.

Although compositions of the oils obtained by SFE and HD were similar, they were quantitatively different. For instance, the best SFE operating conditions ( $9 \mathrm{MPa}, 40^{\circ} \mathrm{C}, 20 \mathrm{~g} / \mathrm{min}$ for $\mathrm{CO}_{2}$ flow-rate) gave more than 3 -fold greater $\alpha$-pinene recovery $(501 \mathrm{mg} / \mathrm{kg}$ 


\begin{tabular}{|c|c|c|c|c|c|c|c|c|c|c|c|}
\hline \multicolumn{12}{|c|}{ Type of process } \\
\hline \multicolumn{6}{|l|}{ SFE } & \multicolumn{4}{|l|}{ Soxhlet } & \multicolumn{2}{|l|}{ HD } \\
\hline 20 & & 20 & & 5 & & & & & & $0.02 \mathrm{~mL} / \mathrm{s}$ & \\
\hline 40 & & 60 & & 40 & & - & - & - & - & - & \\
\hline $\mathrm{CO}_{2}$ & & $\mathrm{CO}_{2}$ & & $\mathrm{CO}_{2}$ & & EtOH & EtOH & EtOH & Hexane & Water & \\
\hline 30 & & 30 & & 30 & & 240 & 360 & 480 & 480 & 180 & \\
\hline 1.6 & & 1.6 & & 0.6 & & 21.2 & 26.8 & 27.4 & 40.4 & 0.61 & \\
\hline \multicolumn{2}{|l|}{$\mathrm{N}^{\circ} 1$} & \multicolumn{2}{|l|}{$\mathrm{N} \circ 2$} & \multicolumn{2}{|l|}{$\mathrm{N} \times 3$} & \multirow[t]{2}{*}{$\mathrm{N}^{\circ} 4$} & \multirow{2}{*}{$\begin{array}{l}\text { N॰5 } \\
\%\end{array}$} & \multirow[t]{2}{*}{$\mathrm{N}^{\circ} 6$} & \multirow{2}{*}{$\begin{array}{l}\mathrm{N}{ }^{\circ 7} \\
\%\end{array}$} & \multicolumn{2}{|l|}{$\mathrm{N}{ }^{\circ} 8$} \\
\hline$\%$ & $(\mathrm{mg} / \mathrm{kg})$ & $\%$ & $(\mathrm{mg} / \mathrm{kg})$ & $\%$ & $\begin{array}{l}(\mathrm{mg} / \\
\mathrm{kg})\end{array}$ & & & & & $\%$ & $\begin{array}{l}(\mathrm{mg} / \\
\mathrm{kg})\end{array}$ \\
\hline $31.32 \pm 1.21^{\mathrm{a}}$ & $501 \pm 22$ & $21.92 \pm 1.43^{\mathrm{c}}$ & $351 \pm 18$ & $9.35 \pm 0.42^{\mathrm{d}}$ & $56 \pm 1$ & $2.68 \pm 0.10^{\mathrm{g}}$ & $3.14 \pm 0.14^{f}$ & $2.63 \pm 0.12^{\mathrm{g}}$ & $6.79 \pm 0.22^{\mathrm{e}}$ & $24.90 \pm 1.08^{b}$ & $152 \pm 6$ \\
\hline $2.64 \pm 0.12^{\mathrm{a}}$ & $42 \pm 1$ & $1.56 \pm 0.09^{c}$ & $25 \pm 1$ & $0.91 \pm 0.04^{\mathrm{d}}$ & $5 \pm 0.2$ & $\begin{array}{l}0.45 \pm 0.02^{\mathrm{f}} \\
5.85 \pm 0.23^{\mathrm{c}}\end{array}$ & $\begin{array}{l}0.53 \pm 0.02^{\mathrm{f}} \\
8.19 \pm 0.42^{\mathrm{a}}\end{array}$ & $\begin{array}{l}0.43 \pm 0.01^{\mathrm{f}} \\
7.28 \pm 0.21^{\mathrm{b}}\end{array}$ & $\begin{array}{l}0.68 \pm 0.02^{\mathrm{e}} \\
4.93 \pm 0.21^{\mathrm{d}}\end{array}$ & $1.99 \pm 0.09^{\mathrm{b}}$ & $12 \pm 0.4$ \\
\hline $0.26 \pm 0.01^{c}$ & $4 \pm 0.1$ & $0.16 \pm 0.01^{\mathrm{d}}$ & $3 \pm 0.1$ & $0.16 \pm 0.00^{\mathrm{d}}$ & $1 \pm 0.08$ & & & & $3.22 \pm 0.11^{\mathrm{a}}$ & $0.37 \pm 0.01^{\mathrm{b}}$ & $2 \pm 0.1$ \\
\hline \multirow{2}{*}{$3.39 \pm 0.15^{\mathrm{a}}$} & $54 \pm 1$ & $2.30 \pm 0.12^{\mathrm{b}}$ & $37 \pm 1$ & $1.50 \pm 0.07^{\mathrm{c}}$ & $9 \pm 0.4$ & & & & $3.32 \pm 0.10^{\mathrm{a}}$ & $3.44 \pm 0.14^{\mathrm{a}}$ & $21 \pm 1$ \\
\hline & & & & & & $13.36 \pm 0.66^{\mathrm{b}}$ & $16.65 \pm 0.72^{\mathrm{a}}$ & $13.87 \pm 0.52^{\mathrm{b}}$ & $4.21 \pm 0.21^{\mathrm{c}}$ & $0.12 \pm 0.01^{\mathrm{d}}$ & $1 \pm 0.04$ \\
\hline $3.44 \pm 0.17^{\mathrm{a}}$ & $55 \pm 2$ & $2.67 \pm 0.12^{\mathrm{b}}$ & $43 \pm 1$ & $3.43 \pm 0.12^{\mathrm{a}}$ & $21 \pm 0.5$ & $1.51 \pm 0.06^{\mathrm{d}}$ & $1.81 \pm 0.07^{\mathrm{c}}$ & $0.95 \pm 0.42^{\mathrm{e}}$ & $1.90 \pm 0.08^{\mathrm{c}}$ & $3.84 \pm 0.16^{a}$ & $23 \pm 1$ \\
\hline $1.25 \pm 0.05^{\mathrm{d}}$ & $20 \pm 1$ & $1.67 \pm 0.7^{c}$ & $27 \pm 1$ & $2.51 \pm 0.08^{\mathrm{b}}$ & $15 \pm 0.6$ & $1.10 \pm 0.05^{\mathrm{e}}$ & $1.57 \pm 0.05^{\mathrm{c}}$ & $0.78 \pm 0.02^{\mathrm{f}}$ & $1.33 \pm 0.06^{\mathrm{d}}$ & $4.36 \pm 0.18^{\mathrm{a}}$ & $27 \pm 0$ \\
\hline $18.18 \pm 0.70^{\mathrm{b}}$ & $291 \pm 12$ & $15.78 \pm 0.7^{\mathrm{c}}$ & $252 \pm 7$ & $17.69 \pm 0.12^{\mathrm{b}}$ & $106 \pm 5$ & $6.15 \pm 0.29^{\mathrm{e}}$ & $5.52 \pm 0.24^{\mathrm{f}}$ & $2.48 \pm 0.11^{\mathrm{g}}$ & $7.44 \pm 0.23^{\mathrm{d}}$ & $21.44 \pm 1.08^{\mathrm{a}}$ & $131 \pm 5$ \\
\hline $1.74 \pm 0.07^{\mathrm{b}}$ & $28 \pm 1$ & $1.73 \pm 0.06^{\mathrm{b}}$ & $28 \pm 1$ & $1.90 \pm 0.06^{\mathrm{a}}$ & $11 \pm 0.6$ & $1.22 \pm 0.06^{\mathrm{c}}$ & $0.75 \pm 0.02^{\mathrm{d}}$ & $0.67 \pm 0.01^{\mathrm{d}}$ & $1.14 \pm 0.04^{\mathrm{c}}$ & $0.44 \pm 0.01^{\mathrm{e}}$ & $3 \pm 0.11$ \\
\hline $4.16 \pm 0.19^{c}$ & $67 \pm 2$ & $5.43 \pm 0.23^{\mathrm{b}}$ & $87 \pm 4$ & $5.81 \pm 0.25^{\mathrm{a}}$ & $35 \pm 0.8$ & $1.51 \pm 0.06^{\mathrm{f}}$ & $1.68 \pm 0.06^{\mathrm{e}}$ & $1.35 \pm 0.06^{\mathrm{g}}$ & $1.71 \pm 0.06^{\mathrm{e}}$ & $2.53 \pm 0.09^{\mathrm{d}}$ & $15 \pm 0.6$ \\
\hline $7.55 \pm 0.31^{\mathrm{c}}$ & $121 \pm 6$ & $11.80 \pm 0.41^{\mathrm{a}}$ & $189 \pm 6$ & $10.86 \pm 0.98^{\mathrm{b}}$ & $65 \pm 2$ & & $2.04 \pm 0.10^{\mathrm{d}}$ & $1.38 \pm 0.05^{\mathrm{e}}$ & $2.03 \pm 0.10^{\mathrm{d}}$ & $1.14 \pm 0.08^{\mathrm{f}}$ & $7 \pm 0.2$ \\
\hline $2.14 \pm 0.10^{\mathrm{e}}$ & $34 \pm 1$ & $3.52 \pm 0.17^{\mathrm{c}}$ & $56 \pm 2$ & $4.75 \pm 0.14^{\mathrm{a}}$ & $29 \pm 0.9$ & $3.96 \pm 0.22^{\mathrm{b}}$ & $2.93 \pm 0.14^{\mathrm{d}}$ & $3.13 \pm 0.12^{\mathrm{d}}$ & $4.03 \pm 0.19^{\mathrm{b}}$ & $0.53 \pm 0.02^{\mathrm{f}}$ & $3 \pm 0.1$ \\
\hline $1.39 \pm 0.05^{\mathrm{d}}$ & $22 \pm 1$ & $1.98 \pm 0.07^{\mathrm{b}}$ & $32 \pm 1$ & $2.76 \pm 0.08^{\mathrm{a}}$ & $17 \pm 0.8$ & & & & & $1.64 \pm 0.06^{c}$ & $10 \pm 0.4$ \\
\hline $1.06 \pm 0.04^{\mathrm{b}}$ & $17 \pm 0.6$ & $3.23 \pm 0.12^{\mathrm{a}}$ & $52 \pm 1$ & $2.43 \pm 0.06^{\mathrm{b}}$ & $15 \pm 0.4$ & & & & & & \\
\hline $1.82 \pm 0.06^{\mathrm{g}}$ & $29 \pm 1$ & $2.88 \pm 0.11^{\mathrm{d}}$ & $46 \pm 2$ & $4.04 \pm 0.18^{\mathrm{b}}$ & $24 \pm 1.2$ & $4.21 \pm 0.19^{\mathrm{a}}$ & $2.44 \pm 0.08^{\mathrm{e}}$ & $2.20^{\mathrm{f}} \pm 0.08$ & $3.54 \pm 0.13^{c}$ & $4.24 \pm 0.11^{\mathrm{a}}$ & $26 \pm 1$ \\
\hline $0.48 \pm 0.02^{\mathrm{e}}$ & $8 \pm 0.3$ & $0.96 \pm 0.03^{\mathrm{d}}$ & $15 \pm 0.4$ & $1.12 \pm 0.05^{c}$ & $7 \pm 0.3$ & $1.56 \pm 0.07^{\mathrm{b}}$ & $1.20 \pm 0.03^{c}$ & $0.93 \pm 0.03^{\mathrm{d}}$ & $1.16 \pm 0.04^{\mathrm{c}}$ & $2.00 \pm 0.08^{\mathrm{a}}$ & $12 \pm 0.3$ \\
\hline $0.52 \pm 0.01^{\mathrm{f}}$ & $8 \pm 0.4$ & $1.23 \pm 0.04^{\mathrm{c}}$ & $20 \pm 0.6$ & $1.67 \pm 0.04^{\mathrm{b}}$ & $10 \pm 0.2$ & $1.17 \pm 0.04^{\mathrm{c}}$ & $0.95 \pm 0.04^{\mathrm{d}}$ & $0.84 \pm 0.02^{\mathrm{e}}$ & $0.92 \pm 0.02^{\mathrm{d}}$ & $2.83 \pm 0.12^{\mathrm{a}}$ & $17 \pm 0.5$ \\
\hline $0.58 \pm 0.02^{\mathrm{g}}$ & $9 \pm 0.2$ & $1.01 \pm 0.03^{\mathrm{f}}$ & $16 \pm 0.6$ & $1.35 \pm 0.06^{\mathrm{d}}$ & $8 \pm 0.1$ & $1.73 \pm 0.07^{\mathrm{b}}$ & $1.53 \pm 0.06^{\mathrm{c}}$ & $1.17 \pm 0.05^{\mathrm{e}}$ & $1.12 \pm 0.02$ & $2.56 \pm 0.09^{\mathrm{a}}$ & $16 \pm 0.4$ \\
\hline $0.43 \pm 0.01^{\mathrm{f}}$ & $7 \pm 0.2$ & $0.77 \pm 0.02^{\mathrm{e}}$ & $12 \pm 0.5$ & $1.05 \pm 0.03^{\mathrm{d}}$ & $6 \pm 0.1$ & $1.50 \pm 0.06^{\mathrm{b}}$ & $1.52 \pm 0.05^{\mathrm{b}}$ & $1.36 \pm 0.06^{c}$ & $1.47 \pm 0.04^{\mathrm{b}}$ & $2.37 \pm 0.11^{\mathrm{a}}$ & $14 \pm 0.3$ \\
\hline \multirow[t]{3}{*}{$0.44 \pm 0.01^{\mathrm{g}}$} & $7 \pm 0.3$ & $1.07 \pm 0.02^{\mathrm{f}}$ & $17 \pm 0.6$ & $1.36 \pm 0.04^{\mathrm{e}}$ & $8 \pm 0.2$ & $2.41 \pm 0.09^{\mathrm{b}}$ & $2.80 \pm 0.13^{\mathrm{a}}$ & $2.24 \pm 0.12^{c}$ & $2.19 \pm 0.11^{\mathrm{c}}$ & $1.74 \pm 0.06^{\mathrm{d}}$ & $11 \pm 0.1$ \\
\hline & & & & $0.31 \pm 0.01^{\mathrm{e}}$ & $2 \pm 0.1$ & $1.96 \pm 0.08^{\mathrm{b}}$ & $2.82 \pm 0.14^{\mathrm{a}}$ & $1.90 \pm 0.08^{\mathrm{c}}$ & $0.82 \pm 0.02^{\mathrm{d}}$ & & \\
\hline & & & & & & $2.69 \pm 0.08^{\mathrm{a}}$ & $1.32 \pm 0.04^{\mathrm{d}}$ & $2.20 \pm 0.11^{\mathrm{b}}$ & $1.52 \pm 0.04^{\mathrm{c}}$ & & \\
\hline $0.40 \pm 0.02^{\mathrm{e}}$ & $6 \pm 0.2$ & $0.40 \pm 0.02^{\mathrm{e}}$ & $6 \pm 0.2$ & $0.59 \pm 0.02^{\mathrm{d}}$ & $4 \pm 0.2$ & $2.26 \pm 0.08^{\mathrm{b}}$ & $2.01 \pm 0.09^{c}$ & $2.20 \pm 0.09^{\mathrm{b}}$ & $2.53 \pm 0.11^{\mathrm{a}}$ & $0.09 \pm 0.00^{\mathrm{f}}$ & $1 \pm 0.1$ \\
\hline $0.13 \pm 0.00^{\mathrm{d}}$ & $2 \pm 0.1$ & $0.16 \pm 0.01^{\mathrm{d}}$ & $3 \pm 0.0$ & $0.27 \pm 0.01^{\mathrm{c}}$ & $2 \pm 0.1$ & $2.14 \pm 0.09^{\mathrm{a}}$ & & $1.83 \pm 0.06^{\mathrm{b}}$ & & $0.27 \pm 0.01^{\mathrm{c}}$ & $2 \pm 0.1$ \\
\hline \multirow[t]{7}{*}{$0.41 \pm 0.01^{\mathrm{h}}$} & $7 \pm 0.3$ & $0.94 \pm 0.03^{\mathrm{f}}$ & $15 \pm 0.6$ & $1.62 \pm 0.06^{\mathrm{e}}$ & $10 \pm 0.4$ & $2.20 \pm 0.11^{\mathrm{c}}$ & $1.76 \pm 0.07^{\mathrm{d}}$ & $2.85 \pm 0.13^{\mathrm{a}}$ & $2.73 \pm 0.12^{\mathrm{b}}$ & $0.52 \pm 0.02^{\mathrm{g}}$ & $3 \pm 0.1$ \\
\hline & & & & & & $4.43 \pm 0.21^{\mathrm{b}}$ & $1.73 \pm 0.08^{\mathrm{d}}$ & $6.54 \pm 0.29^{\mathrm{a}}$ & $3.73 \pm 0.17^{c}$ & & \\
\hline & & & & & & $1.60 \pm 0.09^{\mathrm{d}}$ & $2.53 \pm 0.11^{\mathrm{c}}$ & $5.79 \pm 0.21^{\mathrm{a}}$ & $4.56 \pm 0.20^{\mathrm{b}}$ & & \\
\hline & & & & & & $2.56 \pm 0.11^{\mathrm{b}}$ & $2.99 \pm 0.13^{\mathrm{a}}$ & $2.86 \pm 0.11^{\mathrm{a}}$ & $2.28 \pm 0.11^{c}$ & & \\
\hline & & & & & & $4.41 \pm 0.20^{\mathrm{b}}$ & $5.68 \pm 0.27^{\mathrm{a}}$ & $5.68 \pm 0.26^{a}$ & $0.51 \pm 0.02^{\mathrm{c}}$ & & \\
\hline & & & & & & $4.89 \pm 0.21^{\mathrm{c}}$ & $3.86 \pm 0.17^{\mathrm{d}}$ & $6.26 \pm 0.27^{\mathrm{a}}$ & $5.46 \pm 0.25^{\mathrm{b}}$ & & \\
\hline & & & & & & & & $4.25 \pm 0.18^{\mathrm{a}}$ & & & \\
\hline $0.85 \pm 0.02^{\mathrm{a}}$ & $14 \pm 0.6$ & $0.67 \pm 0.02^{\mathrm{b}}$ & $11 \pm 0.3$ & $0.23 \pm 0.01^{\mathrm{d}}$ & $1 \pm 0.1$ & $0.08 \pm 0.01^{\mathrm{f}}$ & $0.10 \pm 0.00^{\mathrm{f}}$ & $0.09 \pm 0.00^{f}$ & $0.17 \pm 0.01^{\mathrm{e}}$ & $0.39 \pm 0.01^{\mathrm{c}}$ & $2 \pm 0.1$ \\
\hline $0.80 \pm 0.02^{\mathrm{a}}$ & $13 \pm 0.5$ & $0.47 \pm 0.01^{\mathrm{c}}$ & $8 \pm 0.3$ & $0.25 \pm 0.01^{\mathrm{d}}$ & $2 \pm 0.1$ & $0.11 \pm 0.00^{\mathrm{f}}$ & $0.11 \pm 0.01^{\mathrm{f}}$ & $0.09 \pm 0.01^{\mathrm{f}}$ & $0.19 \pm 0.01^{\mathrm{e}}$ & $0.60 \pm 0.02^{\mathrm{b}}$ & $4 \pm 0.3$ \\
\hline $0.33 \pm 0.01^{\mathrm{a}}$ & $5 \pm 0.1$ & $0.14 \pm 0.00^{\mathrm{c}}$ & $2 \pm 0.1$ & $0.24 \pm 0.01^{\mathrm{b}}$ & $1 \pm 0.0$ & & & & & & \\
\hline $0.22 \pm 0.00^{\mathrm{a}}$ & $4 \pm 0.1$ & $0.14 \pm 0.01^{\mathrm{b}}$ & $2 \pm 0.0$ & $0.08 \pm 0.00^{\mathrm{c}}$ & & & & & $0.06 \pm 0.00^{c}$ & $0.14 \pm 0.00^{\mathrm{b}}$ & $1 \pm 0.1$ \\
\hline $0.49 \pm 0.02^{\mathrm{a}}$ & $8 \pm 0.2$ & $0.37 \pm 0.01^{\mathrm{b}}$ & $6 \pm 0.2$ & $0.24 \pm 0.01^{\mathrm{c}}$ & $1 \pm 0.1$ & $0.10 \pm 0.01^{\mathrm{e}}$ & $0.13 \pm 0.01^{\mathrm{e}}$ & $0.10 \pm 0.00^{\mathrm{e}}$ & $0.17 \pm 0.00^{\mathrm{d}}$ & $0.45 \pm 0.02^{\mathrm{a}}$ & $3 \pm 0.2$ \\
\hline $0.43 \pm 0.01^{\mathrm{a}}$ & $7 \pm 0.2$ & $0.22 \pm 0.00^{\mathrm{b}}$ & $4 \pm 0.2$ & $0.29 \pm 0.01^{\mathrm{b}}$ & $2 \pm 0.1$ & & & & & & \\
\hline $0.17 \pm 0.01^{\mathrm{b}}$ & $3 \pm 0.0$ & $0.06 \pm 0.00^{c}$ & $1 \pm 0.0$ & $0.12 \pm 0.01^{\mathrm{b}}$ & $1 \pm 0.1$ & & & & & $0.48 \pm 0.02^{\mathrm{a}}$ & $3 \pm 0.1$ \\
\hline $0.16 \pm 0.01^{\mathrm{a}}$ & $3 \pm 0.1$ & $0.09 \pm 0.00^{c}$ & $1 \pm 0.0$ & $0.10 \pm 0.0^{c}$ & $1 \pm 0.0$ & $0.11 \pm 0.01^{\mathrm{c}}$ & $0.15 \pm 0.01^{\mathrm{a}}$ & $0.13 \pm 0.00^{\mathrm{b}}$ & $0.10 \pm 0.00^{c}$ & $0.18 \pm 0.01^{\mathrm{a}}$ & $1 \pm 0.0$ \\
\hline $0.13 \pm 0.00^{\mathrm{b}}$ & $2 \pm 0.0$ & $0.12 \pm 0.01^{\mathrm{b}}$ & $2 \pm 0.1$ & $0.16 \pm 0.0^{\mathrm{a}}$ & $1 \pm 0.0$ & $0.05 \pm 0.00^{c}$ & $0.07 \pm 0.00^{c}$ & & $0.07 \pm 0.00^{c}$ & & \\
\hline $0.26 \pm 0.01^{c}$ & $4 \pm 0.02$ & $0.14 \pm 0.01^{\mathrm{d}}$ & $2 \pm 0.0$ & $0.16 \pm 0.0^{\mathrm{d}}$ & $1 \pm 0.0$ & $0.26 \pm 0.01^{c}$ & $0.35 \pm 0.01^{\mathrm{b}}$ & $0.28 \pm 0.01^{\mathrm{c}}$ & $0.25 \pm 0.01^{\mathrm{c}}$ & $0.46 \pm 0.01^{\mathrm{a}}$ & $3 \pm 0.1$ \\
\hline
\end{tabular}

Flow rate $(\mathrm{g} / \mathrm{min})$ Temperature $\left({ }^{\circ} \mathrm{C}\right.$

Solvent

Extraction time (min)

Global yield $(\mathrm{g} / \mathrm{kg})$

NI RI Compounds

$\%$

$\begin{array}{lll}1 & 919 & \alpha \text {-pinene } \\ 2 & 967 & \beta \text {-thujene }\end{array}$

3983 Trans-isolimonene

41004 Pseudolimonen

$5 \quad 1008$ 3-Carene

$7 \quad 1128 \quad \alpha$-Campholenal

81148 Camphene hydrate

101266 Linalool acetate

$\begin{array}{lll}11 & 1383 & \beta \text {-Bourbonene } \\ 11 & 1400 & \gamma \text {-Caryophyllene }\end{array}$

$12 \quad 1461$ Alloaromadendrene

$131494 \quad \alpha$-Zingiberene

15 1557 $\quad$ Caryophyllene alcoho

161568 Caryophyllene oxide

171594 Cedrenol

191626 -Epi-cubenol

$19 \quad 1626$-Eudesmo

$21 \quad 1678$ Cis- $\alpha$-santalol

221778 Platambin

231962 Palmitic acid

$25 \quad 2135$ 1R-pimaral

$262216 \quad$ 15-Ripperten-3 $\alpha$-ol

272368 Androst-5-en-17-ol, 4,4 dimethy

$13-v i n y l$
29

$30 \quad 2922$ Abietic acid

31 2925 ni

$32 \quad 2930$ Podocarp-8(14)-en-15al, $13 \beta$-methyl13-vinyl

$\begin{array}{lll}33 & 906 & \text { Santolinatriene } \\ 34 & 931 & \text { Artemeniatilene }\end{array}$

$34 \quad 931 \quad$ Artemesiatriene

36 - 953 a

$37 \quad 953 \quad \alpha$-Fenchene

$38 \quad 973$ 1-ethyl-4-methylbenzene

$\begin{array}{lll}39 & 990 & \text { Myrcene }\end{array}$

$40 \quad 1037$ Limonene

$42 \quad 1068$ Isoterpinolene

$\pm 0.4$

$\pm 0.04$

$\pm 5$

0.6

7.

0.1
$0 \pm 0.4$

0.5

$2.20 \pm 0.11^{\mathrm{c}} \quad 1.76 \pm 0.07^{\mathrm{d}} \quad 2.85 \pm 0.13^{\mathrm{a}}$

$1.60 \pm 0.09 \mathrm{~d}-1.73 \pm 0.08 \mathrm{~d}-6.54 \pm 0.29^{\mathrm{a}}-3$.

$2.56 \pm 0.11^{\mathrm{b}} \quad 2.99 \pm 0.13^{\mathrm{a}} \quad 2.86 \pm 0.11^{\mathrm{a}} \quad 2.28 \pm 0.11^{\mathrm{c}}$

$4.41 \pm 0.20^{\mathrm{b}} \quad 5.68 \pm 0.27^{\mathrm{a}} \quad 5.68 \pm 0.26^{\mathrm{a}} \quad 0.51 \pm 0.02$

$.25 \pm 0.18^{\mathrm{a}}$ 
$43 \quad 1077 \quad$ Ethyl maltol

$\begin{array}{lll}45 & 1089 & \alpha \text {-Terpinolen } \\ 46 & 1108 & \text { Cis-thujone }\end{array}$

$47 \quad 1122$ Trans-2,8-menthadienol

$\begin{array}{lll}48 & 1132 & \text { Isothujol }\end{array}$

$\begin{array}{lll}49 & 1157 & \text { Isoborneol } \\ 50 & 1159 & \beta \text {-Terpineol }\end{array}$

$51 \quad 1172$ 3,5,5-Trimethyl-1,4-cyclohexanedione

521193 Myrtenal

$531200 \quad$ Z-dihydrocarvone

$54 \quad 1232 \quad$ Cis-carveol

551279 p-sec-Butylphenol

561318 (Z)-3-Hexenyl 2-methyl-(E)-2butenoate

$57 \quad 1327 \quad$ Trans-pulegone oxide

$581356 \quad \alpha$-Cubebene

$\begin{array}{lll}59 & 1370 & \text { Cyclosativene } \\ 60 & 1409 & \alpha-\text {-Gurjunene }\end{array}$

$62 \quad 1444 \quad \alpha$-Caryophyllene

$64 \quad 1474 \quad \mathrm{y}$-Muurolene

$661494 \quad \alpha$-Zingiberene

$67 \quad 1501 \quad \alpha$-Amorphene

$681516 \quad \alpha$-Selinene

731673 Cedr-8-en-13-ol

$\begin{array}{lll}76 & 1729 \quad \text { Cis- } \beta \text {-santalol }\end{array}$

$77 \quad 1761 \quad 1,10$-Dihydronootkatone

$78 \quad 1789 \quad 14$-Hydroxy- $\alpha$-muurolene

$79 \quad 1799 \quad$ Alloaromadendrene oxide

$80 \quad 1928 \quad$ 16-Hexadecanolide

811983 Biformene

821991 Manoyl oxide

$\begin{array}{lll}83 & 2008 & \text { Kaur-16-ene } \\ 84 & 2053 & \text { Abietatriene }\end{array}$

852143 Cubitene

$86 \quad 2187$ Cembrene A ketone

$87 \quad 2223$ Trans-totarol

882274 Larixo

$89 \quad 2288 \quad$ ni

902311 Trans-14-Isopropylpodocarpa-8,11,13-

ni: not identified.
$44 \quad 1079$ Artemisia alcohol

$61 \quad 1435 \alpha$-Trans-bergamotene

$63 \quad 1455 \quad \alpha$-Patchoulene

$65 \quad 1479 \quad \mathrm{y}$-Curcumene

$69 \quad 1534$ Incisol

$70 \quad 1588 \quad \beta$-Oplopenone

$71 \quad 1619$ Trans-isolongifolanone

$721660 \quad 14$-Hydroxy-9-epi-(E)-caryophyllene

$74 \quad 1690$ Juniper camphor

751717 Trans-2-heptadecene

$0.32+0.01^{\mathrm{a}}$

$0.25 \pm 0.01^{\mathrm{a}} \quad 2 \pm 0.1$

$\begin{array}{ll}0.25 \pm 0.01^{\mathrm{b}} & 2 \pm 0.0 \\ 0.26 \pm 0.00^{\mathrm{b}} & 2 \pm 0.1\end{array}$

$0.25 \pm 0.01^{\mathrm{a}} \quad 2 \pm 0.1$

$0.29 \pm 0.01^{\mathrm{b}}$

$0.12 \pm 0.01^{\mathrm{c}}$
$0.12 \pm 0.00^{\mathrm{a}}$

$\begin{array}{llllll}0.19 \pm 0.00^{\mathrm{c}} & 0.10 \pm 0.00^{\mathrm{d}} & 0.05 \pm 0.00^{\mathrm{e}} & 0.13 \pm 0.01^{\mathrm{d}} & 0.35 \pm 0.01^{\mathrm{a}} & 2 \pm 0.1\end{array}$ $0.38 \pm 0.01^{\mathrm{a}} \quad 2 \pm 0.0$

$0.16 \pm 0.01^{\mathrm{c}}$

$\begin{array}{ll}0.22 \pm 0.01^{\mathrm{c}} & 1 \pm 0.0 \\ 0.26 \pm 0.00^{\mathrm{c}} & 2 \pm 0.0\end{array}$

$0.41 \pm 0.02^{\mathrm{a}} \quad 2 \pm 0.0 \quad 0.28 \pm 0.00^{\mathrm{c}}$

$0.12 \pm 0.00^{\mathrm{c}}$
$0.13 \pm 0.01^{\mathrm{d}}$
$0.14 \pm 0.1^{\mathrm{d}}$

$0.14 \pm 0.01^{\mathrm{b}}$

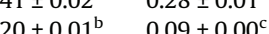

$0.24 \pm 0.00^{\mathrm{b}} \quad 0.11 \pm 0.01$

$0.06 \pm 0.00^{\mathrm{b}} \quad 0.18 \pm 0.00^{\mathrm{a}}$

$0.10 \pm 0.01^{\mathrm{b}}$

$0.33 \pm 0.01^{\mathrm{a}} \quad 2 \pm 0.0$

$0.11 \pm 0.00^{\mathrm{c}} \quad 0.10 \pm 0.00^{\mathrm{c}}$

$\begin{array}{lllllll}0.91 \pm 0.03^{\mathrm{b}} & 15 \pm 0.5 & 0.79 \pm 0.02^{\mathrm{c}} & 13 \pm 0.3 & 0.96 \pm 0.02^{\mathrm{b}} & 6 \pm 0.2 & 0.61 \pm 0.01^{\mathrm{d}}\end{array}$

$0.53 \pm 0.02^{\mathrm{e}}$

$0.73 \pm 0.02^{\mathrm{d}} \quad 0.70 \pm 0.02^{\mathrm{d}}$

$0.36 \pm 0.01^{\mathrm{b}} \quad 0.23 \pm 0.01^{\mathrm{c}}$

$\begin{array}{lll}0.20 \pm 0.01^{\mathrm{b}} & 0.11 \pm 0.00^{\mathrm{c}} \\ 0.03 \pm 0.01^{\mathrm{d}} & 0.51 \pm 0.01^{\mathrm{d}}-0.00 \pm 0.01^{\mathrm{e}}\end{array}$

$0.53 \pm 0.01^{\mathrm{d}} \quad 0.51 \pm 0.01^{\mathrm{d}} \quad 0.40 \pm 0.01^{\mathrm{e}}$

$0.06 \pm 0.00^{\mathrm{b}}$
$0.84 \pm 0.01^{\mathrm{a}}$

$0.08 \pm 0.00^{\mathrm{b}} \quad 0.06 \pm 0.00^{\mathrm{b}}$

$0.64 \pm 0.02^{\mathrm{a}} \quad 0.49 \pm 0.02^{\mathrm{b}}$

$2.93 \pm 0.12^{\mathrm{e}} \quad 3.13 \pm 0.12^{\mathrm{d}}$

$0.37 \pm 0.01^{\mathrm{b}}$

$0.73 \pm 0.02^{\mathrm{a}} \quad 4 \pm 0.1$

$1.41 \pm 0.05^{\mathrm{a}} \quad 9 \pm 0.3$

$\begin{array}{ll}0.16 \pm 0.00^{\mathrm{c}} & 0.08 \pm 0.00^{\mathrm{c}} \\ 0.14 \pm 0.010 & 0.01\end{array}$

$0.14 \pm 0.01^{\mathrm{b}}$

$0.07 \pm 0.00^{\mathrm{b}} \quad 0.58 \pm 0.02^{\mathrm{a}}$

$2 \pm 0.1$

$4 \pm 0.1$

$0.67 \pm 0.02^{\mathrm{d}} \quad 1.53 \pm 0.05^{\mathrm{a}} \quad 9 \pm 0.1$ $0.95 \pm 0.02^{\mathrm{c}} \quad 0.26 \pm 0.00^{\mathrm{e}} \quad 2 \pm 0.1$

$0.37 \pm 0.01^{\mathrm{b}} \quad 0.16 \pm 0.01^{\mathrm{d}} \quad 1 \pm 0.0$

$0.54 \pm 0.02^{\mathrm{d}} \quad 1.04 \pm 0.03^{\mathrm{c}} \quad 6 \pm 0.2$

$0.06 \pm 0.00^{\mathrm{b}} \quad 0.13 \pm 0.00^{\mathrm{a}} \quad 1 \pm 0.0$

$\begin{array}{lll}0.47 \pm 0.01^{\mathrm{b}} & 0.18 \pm 0.01^{\mathrm{e}} & 1 \pm 0.0 \\ & 0.01^{\mathrm{c}} & 2 \pm 0.0\end{array}$

$\begin{array}{lll}4.03 \pm 0.21^{\mathrm{b}} & 0.43 \pm 0.02^{\mathrm{d}} & 3 \pm 0.1 \\ 0.03 \pm 0.01^{\mathrm{g}} & 3 \pm 0.1\end{array}$

$1.64 \pm 0.07^{\mathrm{c}} \quad 10 \pm 0.4$

$\begin{array}{llllll}2.14 \pm 0.10^{\mathrm{d}} & 34 \pm 0.9 & 3.52 \pm 0.15^{\mathrm{c}} & 56 \pm 0.2 & 4.75 \pm 0.21^{\mathrm{a}} & 29 \pm 0.9 \\ 1.39 \pm 0.05^{\mathrm{d}} & 22 \pm 0.7 & 1.98 \pm 0.09^{\mathrm{b}} & 32 \pm 0.1 & 2.76 \pm 0.12^{\mathrm{a}} & 17 \pm 0.6\end{array}$

$\begin{array}{llllll}0.32 \pm 0.01^{\mathrm{a}} & 5 \pm 0.2 & 0.35 \pm 0.01^{\mathrm{a}} & 6 \pm 0.1 & 0.31 \pm 0.01^{\mathrm{a}} & 2 \pm 0.1\end{array}$

$\begin{array}{llll}0.17 \pm 0.00^{\mathrm{f}} & 3 \pm 0.1 & 0.46 \pm 0.01^{\mathrm{e}} \quad 7 \pm 0\end{array}$

$0.44 \pm 0.02^{\mathrm{e}} \quad 3 \pm 0.0$
$0.15 \pm 0.00^{\mathrm{b}} \quad 1 \pm 0.0$

$0.73 \pm 0.02^{\mathrm{a}}$

$0.70 \pm 0.02^{\mathrm{a}} \quad 0.52 \pm 0.02^{\mathrm{d}}$

$0.66 \pm 0.02^{\mathrm{b}} \quad 0.59 \pm 0.02^{\mathrm{c}} \quad 4 \pm 0.1$

$0.38 \pm 0.00^{\mathrm{a}} \quad 2 \pm 0.0$

$0.42 \pm 0.02^{\mathrm{a}} \quad 3 \pm 0.0$

$\begin{array}{lll}0.42 \pm 0.01^{\mathrm{c}} & 0.97 \pm 0.04^{\mathrm{a}} & 6 \pm 0.01 \\ & 0.23 \pm 0.01^{\mathrm{a}} & 1 \pm 0.0\end{array}$

$0.13 \pm 0.01^{\mathrm{c}}$

$1.55 \pm 0.07^{\mathrm{b}}$

$0.69 \pm 0.02^{\mathrm{b}}$

$1.64 \pm 0.02^{a}$
$1.13 \pm 0.04^{a}$

$\begin{array}{llll}0.71 \pm 0.02^{\mathrm{a}} & 0.76 \pm 0.02^{\mathrm{a}} & 0.49 \pm 0.01^{\mathrm{b}} & 0.36 \pm 0.01^{\mathrm{c}} \\ 0.35 \pm 0.01^{\mathrm{b}} & 0.47 \pm 0.01^{\mathrm{a}} & 0.19 \pm 0.01^{\mathrm{c}} & 0.15 \pm 0.00^{\mathrm{c}}\end{array}$

$\begin{array}{lll}0.35 \pm 0.01^{\mathrm{b}} & 0.47 \pm 0.01^{\mathrm{a}} & 0.19 \pm 0.01^{\mathrm{c}} \\ 0.18 \pm 0.01^{\mathrm{c}} & 0.41 \pm 0.01^{\mathrm{a}} & 0.22 \pm 0.01^{\mathrm{c}} \\ 0.79 \pm 0.02^{\mathrm{b}} & 0.43 \pm 0.2^{\mathrm{a}} & 1.39 \pm 0.06^{\mathrm{a}}\end{array}$

$\begin{array}{lllll}0.31 \pm 0.01^{\mathrm{b}} & 2 \pm 0.0 & 0.18 \pm 0.01^{\mathrm{c}} & 0.41 \pm 0.01^{\mathrm{a}} & 0.22 \pm 0.01^{\mathrm{c}} \\ 0.14 \pm 0.00^{\mathrm{d}} & 1 \pm 0.0 & 0.79 \pm 0.02^{\mathrm{b}} & 0.43 \pm 0.02^{\mathrm{c}} & 1.39 \pm 0.06^{\mathrm{a}}\end{array}$

$\begin{array}{lll}0.14 \pm 0.00^{\mathrm{d}} & 1 \pm 0.0 & 0.79 \pm 0.02^{\mathrm{b}} \\ 0.50 \pm 0.02^{\mathrm{c}} & 3 \pm 0.2 & 0.59 \pm 0.01^{\mathrm{b}}\end{array}$

$0.36 \pm 0.01^{\mathrm{e}} \quad 0.43 \pm 0.01^{\mathrm{d}}$

$\begin{array}{ll}0.36 \pm 0.01^{\mathrm{d}} & 0.68 \pm 0.02^{\mathrm{a}} \\ 0.56 \pm 0.02^{\mathrm{c}} & 0.67 \pm 0.01^{\mathrm{b}}\end{array}$

$\begin{array}{lll}0.48 \pm 0.01^{\mathrm{c}} & 3 \pm 0.1 & 0.53 \pm 0.01^{\mathrm{a}} \\ 0.40 \pm 0.01^{\mathrm{e}} & 2 \pm 0.1 & 0.84 \pm 0.02^{\mathrm{a}}\end{array}$

$1.55 \pm 0.05^{\mathrm{b}}$

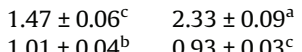

$0.93 \pm 0.03^{\mathrm{c}}$

$\begin{array}{ll}0.66 \pm 0.02^{\mathrm{b}} & 0.29 \pm 0.01^{\mathrm{a}} \\ 0.44 \pm 0.01^{\mathrm{a}}\end{array}$

$\begin{array}{ll}0.95 \pm 0.03^{\mathrm{c}} & 6 \pm 0.2 \\ 0.32 \pm 0.01^{\mathrm{a}} & 2 \pm 0.1\end{array}$

$0.68 \pm 0.02$

$\begin{array}{llll}0.33 \pm 0.01^{\mathrm{b}} & 0.44 \pm 0.01^{\mathrm{a}} & 0.44 \pm 0.01^{\mathrm{a}} & 0.40 \pm 0.01^{\mathrm{a}}\end{array}$

$\begin{array}{lllll}0.67 \pm 0.02^{\mathrm{b}} & 0.52 \pm 0.01^{\mathrm{c}} & 0.74 \pm 0.03^{\mathrm{a}} & 0.62 \pm 0.02^{\mathrm{b}} & 0.07 \pm 0.00^{\mathrm{d}}\end{array}$

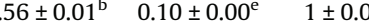
$\begin{array}{lll}0.47 \pm 0.02 & 0.32 \pm 0.00^{\mathrm{f}} \quad 2 \pm 0.1\end{array}$

.

$0.14 \pm 0.01^{\mathrm{f}} \quad 1 \pm 0.0$

Tentatively identified supported by good match of MS. Values within lines with different superscripts (a-h) were significantly different. Relative standard deviation (RSD): RSD $<5 \%$ for percentage of compounds $>0.2 \%$ and RSD $>5 \%$ for percentage of compounds $<0.2 \%$. 
compared to $152 \mathrm{mg} / \mathrm{kg}$ ). Because both extractions were performed up to completion, it can be postulated that such compounds were thermally degraded in the case of HD and therefore were not recovered at the condenser. Such reasoning is supported by the fact that more caryophyllene oxide was present in HD than in SFE, indicating a probable degradation of caryophyllene into its oxidized form. These results demonstrate that shorter duration of operation at lower temperature is one of the main advantages of SFE over HD. Therefore, SFE appears to be the optimum process for obtaining $T$. articulata volatile oil of high quality with a good yield. Costa et al. (2012) obtained similar results when processing leaves from Lavandula viridis, where higher yields were achieved by SFE than by HD. Also, Pavela, Sajfrtová, Sovová, Bárnet and Karban (2010) obtained higher yield for SFE compared to HD when processing Tanacetum parthenium (L.).

When operating SFE, a change of the extraction temperature in the extractor has an effect on the chemical composition of the extracts and $40^{\circ} \mathrm{C}$ seems to be the best condition. It is probable that, at $60{ }^{\circ} \mathrm{C}$, the solubility of solutes decreases because of the retrograde solubility phenomenon specific to supercritical fluids.

Because it has been postulated that extraction is mainly solubility limited, experiment $\mathrm{N}^{\circ}$, where the $\mathrm{CO}_{2}$ flow-rate was reduced to $5 \mathrm{~g} / \mathrm{min}$ (instead of $20 \mathrm{~g} / \mathrm{min}$ ), can be interpreted as being equivalent to a shorter duration experiment at $20 \mathrm{~g} / \mathrm{min}$ of $\mathrm{CO}_{2}$, i.e. 7.5 min duration. So it logically results in a lower yield $(0.6 \mathrm{~g} / \mathrm{kg}$ compared to $1.6 \mathrm{~g} / \mathrm{kg}$ ). Also, decreasing the flow-rate of $\mathrm{CO}_{2}$ at constant temperature decreases the proportion of monoterpene hydrocarbons $(40.56-13.1 \%$ or $40.56-27.96 \%$, respectively) while it increases the proportion of oxygenated sesquiterpenes (5.64$14.6 \%$ or $5.64-12.32 \%$, respectively) and sesquiterpene hydrocarbons (21.76-31.2\% or $21.76-29.20 \%$, respectively), indicating a selectively favored extraction of the latter.

All Soxhlet extractions gave significantly higher yields than HD or SFE (from 26 to $40 \mathrm{~g} / \mathrm{kg}$, as can be seen in Table 1). This procedure allows the extraction of volatile compounds but also high molecular-mass compounds, which proved to be present in large amounts. Because such heavy compounds cannot be detected by GC-MS, it was not possible to calculate the amounts extracted as for HD and SFE, so they are not given in Table 1.

\subsection{Phenolic composition}

Polyphenols are used for the prevention of various diseases that are mainly associated with free radicals. More generally, phenolic compounds have been recognized as antioxidant agents, which act as free radical terminators and have been known to exhibit medicinal activity as well as physiological functions (Rawat, Bhatt, \& Rawal, 2011).

The total phenolic composition of the extracts was measured and the results are summarized in Table 2. The total phenolic content varied from 2.3 to $38.1 \mathrm{mg}$ of Gallic Acid Equivalent (GAE)/g dry plant material. A wide range of phenolic concentrations was observed in the extracts. EO obtained by HD $(24.6 \pm 0.2 \mathrm{mg} \mathrm{GAE} / \mathrm{g}$ dry plant material) and the volatile fraction obtained by SFE (4.4-2.3 mg GAE/g dry plant material) contained very much smaller amounts of phenolic compounds than did ethanol Soxhlet extract $(38.1 \pm 0.6 \mathrm{mg} \mathrm{GAE} / \mathrm{g}$ dry plant material) and hexane Soxhlet extract $(26.3 \pm 0.4 \mathrm{mg}$ GAE/g dry plant material). These results are novel because the occurrence of large quantities of phenolic compounds in $T$. articulata from Tunisia has not been reported previously.

\subsection{Antioxidant activity}

The antioxidant activity of extracts was assessed by two tests measuring the antiradical activity: the $\mathrm{DPPH}^{\bullet}$ and $\mathrm{ABTS}^{\bullet+}$ methods.
Table 2

Total phenolics and antioxidant activity of $T$ articulata extracts obtained by HD, Soxhlet and SFE.

\begin{tabular}{llccc}
\hline & Samples & $\begin{array}{l}\text { Phenolics } \\
(\mathrm{g} \mathrm{GAE} / \mathrm{kg} \text { dry } \\
\text { mass })^{\mathrm{a}}\end{array}$ & $\begin{array}{l}\mathrm{DPPH}^{\bullet} \mathrm{IC}_{50} \\
(\mathrm{mg} / \mathrm{L})\end{array}$ & $\begin{array}{l}\mathrm{ABTS}^{\bullet+} \mathrm{IC}_{50} \\
(\mathrm{mg} / \mathrm{L})\end{array}$ \\
\hline SFE & $\mathrm{N}^{\circ} 1$ & $1.08 \pm 0.06^{\mathrm{b}}$ & $182 \pm 6^{\mathrm{b}}$ & $45 \pm 2^{\mathrm{a}}$ \\
& $\mathrm{N}^{\circ} 2$ & $1.18 \pm 0.02^{\mathrm{b}}$ & $146 \pm 2^{\mathrm{a}}$ & $41 \pm 1^{\mathrm{a}}$ \\
SOXHLET & $\mathrm{N}^{\circ} 3$ & $0.49 \pm 0.00^{\mathrm{a}}$ & $243 \pm 10^{\mathrm{c}}$ & $97 \pm 3^{\mathrm{c}}$ \\
& $\mathrm{N}^{\circ} 4$ & $11.52 \pm 0.16^{\mathrm{d}}$ & $2669 \pm 125^{\mathrm{g}}$ & $375 \pm 18^{\mathrm{f}}$ \\
& $\mathrm{N}^{\circ} 5$ & $32.90 \pm 1.60^{\mathrm{e}}$ & $1110 \pm 55^{\mathrm{e}}$ & $51 \pm 2^{\mathrm{b}}$ \\
Hydrodistillation & $\mathrm{N}^{\circ} 6$ & $89.70 \pm 3.00^{\mathrm{f}}$ & $1836 \pm 61^{\mathrm{f}}$ & $293 \pm 14^{\mathrm{d}}$ \\
Vitamin C & $\mathrm{N}^{\circ} 8$ & $140.50 \pm 9.00^{\mathrm{g}}$ & $943 \pm 50^{\mathrm{d}}$ & $281 \pm 8^{\mathrm{d}}$ \\
& - & $8.89 \pm 0.16^{\mathrm{c}}$ & $3681 \pm 69^{\mathrm{h}}$ & $324 \pm 14^{\mathrm{e}}$ \\
\hline
\end{tabular}

Values within columns with different superscripts $(\mathrm{a}-\mathrm{h})$ were significantly different $(p<0.05)$.

A comparison of the antioxidant activity, assessed by both $\mathrm{DPPH}^{\bullet}$ and $\mathrm{ABTS}^{\bullet+}$ assays, is presented in Table 2.

The differences between DPPH ${ }^{\bullet}$ and $\mathrm{ABTS}^{\bullet+}$ tests can be explained by the mechanism of the reactions involved. The ABTS ${ }^{\circ+}$ cation radical reactions involve electron transfer and take place at a much faster rate than those for $\mathrm{DPPH}^{\bullet}$ radicals, whose degree of discoloration is attributed to the hydrogen donating ability of the tested compounds. The general trend obtained for the different tested extracts is the same by the two methods (Bendaoud, Romdhane, Souchard, Cazaux, \& Bouajila, 2010).

For the DPPH ${ }^{\bullet}$ assay, the values varied from 108 to $242 \mathrm{mg} / \mathrm{L}$ for the SFE extracts, from 943 to $2668 \mathrm{mg} / \mathrm{L}$ for the Soxhlet extracts and, finally, were equal to $3681 \mathrm{mg} / \mathrm{L}$ for HD EO. T. articulata EO obtained by HD ( $3681 \pm 69 \mathrm{mg} / \mathrm{L}$ by DPPH assay) exhibited a low antioxidant activity and this result is in accordance with the one obtained by Ben Hadj Ahmed et al. (2011) (1214.13 mg/L by DPPH assay) with $T$. articulata from Algeria. For the $\mathrm{ABTS}^{\circ+}$ assay, the values varied from 29 to $96 \mathrm{mg} / \mathrm{L}$ for the SFE extracts, 51 to $375 \mathrm{mg} / \mathrm{L}$ for the Soxhlet extracts and, finally, $324 \mathrm{mg} / \mathrm{L}$ for HD EO. From both tests, it appears that extracts obtained from SFE at $9 \mathrm{MPa}$ exhibit the highest antioxidant activity $\left(146 \mathrm{mg} / \mathrm{L}\right.$ for $\mathrm{DPPH}^{\bullet}$ and $41 \mathrm{mg} / \mathrm{L}$ for $\mathrm{ABTS}^{\bullet+}$ ). In contrast, EO of T. articulata obtained by HD exhibited quite a low antioxidant activity $\left(3681.49 \mathrm{mg} / \mathrm{L}\right.$ for $\mathrm{DPPH}^{\bullet}$ and $324.45 \mathrm{mg} / \mathrm{L}_{\text {for }} \mathrm{ABTS}^{\circ+}$ ). The Soxhlet extracts exhibited intermediate activities.

For SFE extraction, the influence of temperature so as $\mathrm{CO}_{2}$ flowrate at a constant pressure ( $9 \mathrm{MPa}$ ) on antioxidant activity was tested. The results show that an increase in temperature (40$60{ }^{\circ} \mathrm{C}$ ) increased the antioxidant activity, probably indicating a correlative increase in the solvent power of $\mathrm{CO}_{2}$. Varying the $\mathrm{CO}_{2}$ flowrate (from $20 \mathrm{~g} / \mathrm{min}$ to $5 \mathrm{~g} / \mathrm{min}$ ) decreased the antioxidant activity $(45 \pm 2-97 \pm 3 \mathrm{mg} / \mathrm{L})$ of the extract.

This result can be explained by the fact that, for the chosen extraction time, because the extraction process is postulated to be limited by solubility, the extraction at $20 \mathrm{~g} / \mathrm{min}$ was complete but this is not true at $5 \mathrm{~g} / \mathrm{min}$. So, compounds contributing to antioxidant activity are not fully recovered.

Similarly, for the Soxhlet extraction, two solvents were tested and extraction time was varied in the case of ethanol. In this case, the results show an optimum extraction time of $6 \mathrm{~h}$ with a good antioxidant activity of the extracts $(51 \pm 2 \mathrm{mg} / \mathrm{L})$. Also, it can be noted that the antioxidant activity of the extracts was higher with hexane than with ethanol as the solvent.

These results suggest that SFE makes it possible to recover one or more compounds with high antioxidant properties while these compounds are not extractable with HD or organic solvent extraction. A better hypothesis could be that, in the case of HD or Soxhlet extraction, these active compounds are destroyed because they are 
exposed to high temperature for a long time in these two methods. This highlights one of the main interests of the SFE process as compared to traditional extraction techniques (Nerio, Olivero-Verbel, \& Stashenko, 2010).

Antioxidant activity is often due to the presence of phenolic compounds but, in this case, few phenolics were found in SFE extracts and a first hypothesis could be that other compounds extracted by SFE are responsible for the antioxidant activity.

However, when the relation between total phenolic content and antioxidant activity was analyzed, the results showed a good correlation $\left(R^{2}=0.6\right.$ for $\mathrm{ABTS}^{\bullet+}$ and $R^{2}=0.87$ for $\left.\mathrm{DPPH}^{\bullet}\right)$ between the antioxidant activity and the phenolic content. So, it can be postulated that, even at low concentration, phenolics present in the SFE extracts are probably very active molecules that have been extracted and preserved from thermal degradation by the SFE procedure.

The correlation between the amount of total polyphenols and antioxidant activity is original and is confirmed for SFE for the first time.

\section{Conclusions}

The extraction of EO of T. articulata was studied using HD, Soxhlet and SFE methods. The best results for SFE were obtained at $40{ }^{\circ} \mathrm{C}$ and $9 \mathrm{MPa}$ and provided selective recovery of the volatile fraction. SFE was rapid (30 min) compared to HD (3 h) and Soxhlet $(6 \mathrm{~h})$, and the yield $(1.6 \mathrm{~g} / \mathrm{kg}$ ) was improved as compared to HD $(0.6 \mathrm{~g} / \mathrm{kg})$, most probably because of reduced thermal degradation of the extracted compounds. Interesting selectivity for compounds with high antioxidant activity $(41 \pm 1 \mathrm{mg} / \mathrm{L})$ and correlation between phenolic content and antioxidant activity were observed for SFE extracts. Although solvent Soxhlet extractions have provided good results, their use as an industrial process is questionable, mainly from the hazards they generate, either because of their toxicity or their flammability. The use of a clean solvent like $\mathrm{CO}_{2}$ exhibits none of these drawbacks, which are now considered as non acceptable flaws, and in addition preserves the products from long time exposure to high temperature. This is often a good incentive to overcome the drawback of higher investment costs related to the supercritical extraction technology.

\section{References}

Barrero, A. F., Moral, J. F. Q., Lucas, R., Paya, M., Akssira, M., Akaad, S., et al. (2003). Diterpenoids from Tetraclinis articulata that inhibit various human leukocyte functions. Journal of Natural Products, 66, 844-850.

Ben Hadj Ahmed, S., Sghaier, R. M., Guesmi, F., Kaabi, B., Mejri, M., Attia, H., Laouini, D., \& Smaali, I. (2011). Evaluation of antileishmanial, cytotoxic and antioxidant activities of essential oils extracted from plants issued from the leishmaniasisendemic region of Sned (Tunisia). Natural Product Research: Formerly Natural Product Letters, 25(12), 1195-1201.

Bendaoud, H., Romdhane, M., Souchard, J. P., Cazaux, S., \& Bouajila, J. (2010). Chemical composition and anticancer and antioxidant activities of Schinus Molle L. and Schinus terebinthifolius Raddi berries essential oils. Journal of Food Science, 75(6), 466-472.

Blois, M. S. (1958). Antioxidant determinations by the use of a stable free radical. Nature, 181, 1199-1200.

Bourkhiss, M., Hnach, M., Paolini, J., Costa, J., Farah, A., \& Satrani, B. (2010). Propriétés antioxidantes et anti-inflammatoires des huiles essentielles des différentes parties de Tetraclinis articulata (Vahl) masters du Maroc. Bulletin de la Société Royale des Sciences de Liège, 79, 141-154.

Costa, P., Grosso, C., Gonçalves, S., Andrade, P. B., Valentão, P., Bernardo-Gil, M. G., et al. (2012). Supercritical fluid extraction and hydrodistillation for the recovery of bioactive compounds from Lavandula viridis L'Hér. Food Chemistry, 135, $112-121$.

da Francisco, J. C., \& Sivik, B. (2002). Solubility of three monoterpenes, their mixtures and eucalyptus leaf oils in dense carbon dioxide. The Journal of Supercritical Fluids, 23, 11-19.

Gomes, P. B., Mata, V. G., \& Rodrigues, A. E. (2007). Production of rose geranium oil using supercritical fluid extraction. The Journal of Supercritical Fluids, 41, 50-60.

Grosso, C., Ferraro, V., Figueiredo, A. C., Barroso, J. G., \& Palavra, A. M. (2008). Supercritical carbon dioxide extraction of volatile oil from Italian coriander seeds. Food Chemistry, 111, 197-203.
Guan, W., Li, S., Yan, R., Tang, S., \& Quan, C. (2007). Comparison of essential oils of clove buds extracted with supercritical carbon dioxide and other three traditional extraction methods. Food Chemistry, 101, 1558-1564.

Hawthorne, S. B., Grabanski, C. B., Martin, E., \& Miller, D. J. (2000). Comparisons of soxhlet extraction, pressurized liquid extraction, supercritical fluid extraction and subcritical water extraction for environmental solids: recovery, selectivity and effects on sample matrix. Journal of Chromatography A, 892, 421-433.

Herrero, M., Mendiola, J. A., Cifuentes, A., \& Ibanez, E. (2010). Supercritical fluid extraction: Recent advances and applications review. Journal of Chromatography A, 1217, 2495-2511.

Kelen, M., \& Tepe, B. (2008). Chemical composition, antioxidant and antimicrobial properties of the essential oils of three Salvia species from Turkish flora. Bioresource Technology, 99, 4096-4104.

Khajeh, M., Yamini, Y., Bahramifar, N., Sefidkon, F., \& Pirmoradei, M. R. (2005). Comparison of essential oils compositions of Ferula assa-foetida obtained by supercritical carbon dioxide extraction and hydrodistillation methods. Food Chemistry, 91, 639-644.

Khajeh, M., Yamini, Y., Sefidkon, F., \& Bahramifar, N. (2004). Comparison of essential oil composition of Carum copticum obtained by supercritical carbon dioxide extraction and hydrodistillation methods. Food Chemistry, 86, 587-591.

Khajeh, M., Yamini, Y., \& Shariati, S. (2010). Comparison of essential oils compositions of Nepetapersica obtained by supercritical carbon dioxide extraction and steam distillation methods. Food and Bioproducts Processing, 88, 227-232.

Mara, M. E., Leal, P. F., Carvalho, J. E., \& Meireles, M. A. (2003). Comparison of yield, composition, and antioxidant activity of turmeric (Curcuma longa L.) extracts obtained using various techniques. Journal of Agricultural and Food Chemistry, 51, 6604-6611.

Morales, M. T., Berry, A. J., McIntyre, P. S., \& Aparicio, R. (1998). Tentative analysis of virgin olive oil aroma by supercritical fluid extraction-high-resolution gas chromatography-mass spectrometry. Journal of Chromatography A, 819, 267-275.

Nerio, L. S., Olivero-Verbel, J., \& Stashenko, E. (2010). Repellent activity of essential oils: A review. Bioresource Technology, 101, 372-378.

Patel, D. K., Kumar, R., Laloo, D., \& Hemalatha, S. (2012). Natural medicines from plant source used for therapy of diabetes mellitus: An overview of its pharmacological aspects. Asian Pacific Journal of Tropical Disease, 239-250.

Pavela, R., Sajfrtov, M., Sovova, H., Barnet, M., \& Karban, J. (2010). The insecticidal activity of Tanacetumparthenium (L.) Schultz Bip. Extracts obtained by supercritical fluid extraction and hydrodistillation. Industrial Crops and Products, 31, 449-454.

Rashid, S., Rather, M. A., Shah, W. A., \& Bhat, B. A. (2013). Chemical composition, antimicrobial, cytotoxic and antioxidant activities of the essential oil of Artemisia indica Willd. Food Chemistry, 138, 693-700.

Rawat, S., Bhatt, I. D., \& Rawal, R. S. (2011). Total phenolic compounds and antioxidant potential of Hedychium spicatum Buch. Ham. ex D. Don in West Himalaya, India. Journal of Food Composition and Analysis, 24, 574-579.

Re, R., Pellegrini, N., Proteggente, A., Pannala, A., Yang, M., \& Rice-Evans, C. (1999). Antioxidant activity applying an improved ABTS radical cation decolorization assay. Free Radical Biology Medicine, 26, 1231-1237.

Reverchon, E. (1997). Supercritical extraction and fractionation of essential oils and related products. The Journal of Supercritical Fluids, 10, 1-37.

Reverchon, E., Ambruosi, A., \& Senatore, F. (1994). Isolation of peppermint oil using supercritical $\mathrm{CO}_{2}$ extraction. Flavour and Fragrance Journal, 9, 19-23.

Sacchetti, G., Maietti, S., Muzzoli, M., Scaglianti, M., Manfredini, S., Radice, M., et al. (2005). Comparative evaluation of 11 essential oils of different origin as functional antioxidants, antiradicals and antimicrobials in foods. Food Chemistry, 91, 621-632.

Sanchez-Gonzalez, L., Vargas, M., Gonzalez-Martınez, C., Chiralt, A., \& Chafer, M. (2011). Use of essential oils in bioactive edible coatings. Food Engineering Reviews, 3, 1-16.

Schaneberg, B. T., \& Khan, I. A. (2002). Comparison of extraction methods for marker compounds in the essential oil of lemon grass by GC. Journal of Agricultural and Food Chemistry, 50, 1345-1349.

Shee, A. K., Raja, B. R., Sethi, D., Kunhambu, A., \& Arunachalam, K. D. (2010). Studies on the current antibacterial activity potential of commonly used food preservatives. International Journal of Engineering and Technology, 2, 264-269.

Singleton, V. L., Orthofer, R., \& Lamuela-Raventós, R. M. (1999). Analysis of total phenols and other oxidation substrates and antioxidants by means of folinciocalteu reagent. Methods in Enzymology, 299, 152-178.

Sovová, H., \& Aleksovski, S. A. (2006). Mathematical model for hydrodistillation of essential oils. Flavour and Fragrance Journal, 21, 881-889.

Sovova, H., Komers, R., Kucera, J., \& Jez, J. (1994). Supercritical carbon dioxide extraction of caraway essential oil. Chemical Engineering Science, 49, 2499-2505.

Thaipong, K., Boonprakob, U., Crosby, K., Zevallos, L. C., \& Byrne, D. H. (2006). Comparison of $\mathrm{ABTS}^{\circ+}$, DPPH*, FRAP, and ORAC assays for estimating antioxidant activity from guava fruit extracts. Journal of Food Composition and Analysis, 19, 669-675.

Vergas, C. E., Mendes, M. F., Azevedo, D. A., Pessoa, F. L. P., \& Uller, A. C. (2010). Extraction of the essential oil of abajeru (Chrysobalanus icaco) using supercritical $\mathrm{CO}_{2}$. The Journal of Supercritical Fluids, 54, 171-177.

Yamini, Y., Khajeh, M., Ghasemi, E., Mirza, M., \& Javidnia, K. (2008). Comparison of essential oil compositions of Salvia mirzayanii obtained by supercritical carbon dioxide extraction and hydrodistillation methods. Food Chemistry, 108, $341-346$. 